\title{
Design ANd Evaluation of Auto-ID EnABLed Shopping Assistance ARTIFACTS In CUSTOMERS' MOBILE PHONES: TWO RETAIL STORE LABORATORY EXPERIMENTS ${ }^{1}$
}

\author{
Viswanath Venkatesh, John A. Aloysius, Hartmut Hoehle, and Scot Burton \\ Sam M. Walton College of Business, University of Arkansas, Fayetteville, AR 72701 U.S.A. \\ \{vvenkatesh@vvenkatesh.us\} \{jaloysius@walton.uark.edu\} \\ \{hhoehle@walton.uark.edu\}\{sburton@walton.uark.edu\}
}

\begin{abstract}
There has been widespread use of auto-ID technologies. With the increasing diffusion of smartphones, the potential to serve content to shoppers using auto-ID technologies is starting to receive interest. Using a design science approach, we design and build, theorize about, and compare six shopping assistance artifacts by manipulating the hardware design — barcode scanner versus radio frequency identification (RFID) reader - and content design - product information versus product review versus both. We theorize about how these artifact conditions will compare to a control condition (no shopping assistance artifact available) across three sets of outcomes: technology adoption, security beliefs, and shopping. We tested our propositions in two experiments-wherein the task was varied: general browsing and shopping $(n=227)$ versus goal-directed shopping $(n=221)$-conducted in a retail store laboratory. The RFID reader was most favorably received in terms of technology adoption outcomes and shopping outcomes, although it was most negatively viewed in terms of security beliefs. We also found that the content design conditions (i.e., product information, product reviews, and both) were perceived favorably. In a post hoc analysis, we found a two-way interaction of hardware and content designs such that content fueled by RFID was perceived most favorably in terms of technology adoption and shopping outcomes, whereas it was most negatively viewed in terms of security beliefs. Interestingly, the two-way interaction was most pronounced in the goal-directed shopping condition such that the most positive effects were observed for RFID in combination with both product information and reviews.
\end{abstract}

Keywords: Auto-ID technologies, RFID, product reviews, technology adoption

\section{Introduction}

The recent proliferation of mobile technological devices, such as smartphones, has resulted in retailers and application providers exploring mobile applications that use auto-ID technologies, such as barcodes and RFID. ${ }^{2}$ In 2012, 48\% of U.S.-

\footnotetext{
${ }^{1}$ Eric Ngai was the accepting senior editor for this paper.

${ }^{2}$ A mobile application is software specifically designed for mobile operating systems installed on hand-held devices, such as smartphones (e.g., iPhones) or tablet computers (e.g., iPad). Auto-ID technologies refer to devices that can capture data without the intervention of human intelligence, including
}

based retailers listed engagement with customers ${ }^{3}$ through their mobile devices as a top priority (RIS Research 2012a). These retailers (e.g., mass merchandisers, department stores, and specialty stores) are exploring mobile applications that will help in-store customer (i.e., shopper) purchase decisions with auto-ID scanning functions that provide product descrip-

barcodes, RIFD, magnetic identification, biometric technologies, and optical character reters (OCR) (RFID Journal n.d.).

\footnotetext{
${ }^{3}$ We use the terms customer and consumer interchangeably in this paper. We stay faithful to the term used in various literature bases (e.g., the term consumer behavior is used in the literature base in marketing).
} 
tions and customer product reviews. Leveraging customers' mobile devices and auto-ID technologies in an in-store shopping context brings to center stage the design of appropriate mobile applications. Mobile applications in general have become well accepted among customers, with a recent study showing that about half of all U.S. customers own smartphones and more than half of those owners reported using them on their shopping trips (RIS Research 2012b). The ratio of visitors who purchase products as a result of their visit in a retail store using a retailer's mobile application is $21 \%$ higher than for those who do not use a mobile application. In 2012, the estimates were that this would influence about $5 \%$ of all retail store purchases accounting for over $\$ 150$ billion in sales (RIS Research 2012b). Increasingly, firms recognize that apps on mobile phones can enhance shopper visibility of products and thereby potentially enhance customer service and experience, as well as help to drive sales (e.g., Hong et al. 2006; Hong et al. 2008; Ngai and Gunasekaran 2007).

One way to leverage mobile applications beyond downloadable shopping-related applications is by using auto-ID technologies such as barcodes (universal product codes or UPC) and RFID (electronic product codes or EPC) in retail stores. Although these technologies have been primarily used to provide point-of-sale data capture and a means to track and update records (Hardgrave et al. 2011; Ngai, To et al. 2009), they can also be used in combination with mobile applications to enhance shoppers' in-store experience. Although barcodes provide inventory visibility, the technology is limited in that it requires optical line-of-sight for data capture, whereas RFID has an advantage over barcodes in that RFID data capture does not require line-of-sight (McFarlane and Sheffi 2003).

The focus with customer applications is on product information visibility for the shopper. Given the success of online shopping assistant applications, such as Amazon, Groupon, and Google Shopper, modern retailers recognize that shoppers appreciate having online access to product information and product reviews from peers who have previously bought and evaluated the products (e.g., Chan et al. 2010; Hong and Tam 2006; Hong et al. 2007; Ngai and Wat 2002). In fact, recent research shows that customers view positive product reviews as a signal of product quality, which in turn impacts retailers' pricing strategies ( $\mathrm{Li}$ and Hitt 2010; Li et al. 2011). With increased access to information through smartphones, customers have more information available when shopping in a retail store, thus further changing the information environment that may influence customers' responses and purchase decisions (e.g., Thong et al. 2006; Thong et al. 2011; Venkatesh et al. 2012).
Given the rapid evolution of new technologies, retailers are thinking about different ways to leverage technologies to enhance shopper experience and convenience (NFC World 2012; RFID Journal 2012). However, many customers have initially resisted embracing the notion of having tagged products that can be traced in stores by RFID readers (Bose et al. 2009; Ngai, Poon et al. 2009; Thiesse 2007). For example, when the German retailer Metro announced the use of RFID in its concept store, protesters complained about the use of RFID due to privacy and risk concerns, as well as their lack of trust in the retailer and mistrust in RFID (Thiesse 2007). Likewise, although there are a variety of technological applications that perform each function separately (e.g., providing product information on the spot via a barcode scanner), the retail industry is working on solutions that integrate RFID and mobile shopping applications seamlessly to offer product information and product reviews on the spot (RIS Research 2012b). Thus, research that can aid in our understanding of customers' reactions to different emerging technology choices will be valuable to retailers in making appropriate investments in in-store technology hardware and software aids for shoppers.

Although there is a considerable amount of research that has studied technologies in general, including auto-ID technologies in particular, there is a lack of research on how this emerging hardware design (e.g., barcode scanner, RFID reader) and content design (e.g., product information, product reviews) can be leveraged by retail stores to benefit customers and, consequently, contribute to a better overall shopping experience. To address this gap, we use a design science approach to design and evaluate our artifacts. We applied the eight components of design theory proposed by Gregor and Jones (2007). A design science approach was chosen due to the fact that it places emphasis on clarifying the goals and underlying theoretical constructs for a new artifact (Gregor and Jones 2007; McLaren et al. 2011; Moon and Ngai 2010). Our objectives and approach are as follows:

(1) Design-and-build artifacts: We use cutting-edge technologies to manipulate both the hardware design and content design. Specifically, we employ shopping assistance artifacts that use one of two hardware designs (i.e., barcode scanner or RFID reader). The content design of these artifacts was varied based on the content served (i.e., product information, product reviews, or both).

(2) Theorize about artifacts: Relevant to the context of the shopping assistance artifacts, we identify relevant concepts and constructs (i.e., outcomes) on which we assess the impacts of the artifacts. Specifically, we theorize about which hardware design and content design will have more (or less) favorable impacts on different outcomes. 
(3) Test-and-compare artifacts: Using a retail store laboratory, we conduct two empirical studies, wherein the nature of the shopping task is varied, to examine the effects of the artifacts on various outcomes. By comparing different artifacts, we specifically assess which artifact is better received by customers and draw conclusions about the best/better designs.

\section{Theory}

In order to accomplish our objectives and to help understand the potential likelihood of success of the different technology choices being considered, we turned to three major streams of research that we felt could inform our thinking: (1) auto-ID technologies, with a particular emphasis on RFID; (2) technology adoption, usability, and e-commerce research; and (3) marketing research on customers' reactions. We first review the literature on auto-ID technologies and RFID and discuss an important gap in this stream. Then, we discuss the prior work on technology adoption, usability, and e-commerce, and discuss its relevance to our work. Next, we turn to marketing research on customer reactions because it helps us in understanding how to evaluate auto-ID enabled shopping assistance artifacts in retail settings.

\section{Background Auto-ID Technologies and Visibility}

We discuss research on RFID adoption, with a particular emphasis on how RFID enables inventory and product visibility in organizations. Early research on auto-ID technologies was fueled more recently in concert with the managerial interests and concerns discussed earlier, and has focused heavily on barcode technologies and RFID (see Ngai and Gunasekaran 2007). Similarly, prior research on RFID has primarily studied the impact of RFID on the business operations of retailers (Hardgrave et al. 2011; Ngai, Poon et al. 2009). Few studies have investigated how RFID can be leveraged as an information source within the store in an effort to increase sales (for an example, see Aloysius et al. 2013). In addition, few studies have investigated RFID adoption at the individual level and those studies investigated RFID using technology adoption theories (see Kim and Garrison 2009), with the primary findings indicating that privacy concerns, trust, and risk influence individuals' intentions to use RFID. Furthermore, our literature review suggested that most studies did not examine individuals' reactions regarding their experiences with actual RFID artifacts, but rather used the term RFID as part of the interview protocols and asked respondents to report their perceptions of RFID. Interestingly, customer reactions to RFID implementations at major retail stores, such as Metro (see Thiesse 2007), appeared to be heavily negatively biased by news reports and have typically failed to capture customer views in actual usage contexts.

RFID has been shown to provide inventory visibility, which is the ability to determine the location of a unit of inventory, both upstream in the supply chain (Delen et al. 2007) and internally in the store (Hardgrave et al. 2013). Although early RFID research focused on technology issues, there has been a more recent focus on the impact on marketing and customer applications (Ngai et al. 2008). Retailers have explored autoID technology in combination with mobile technology in order to provide product visibility for shoppers (Businesswire 2011), which is a shopper's ability to access information on product attributes and on others' preferences for and opinions about the product. RFID can also provide the ability to monitor shopper preferences-in the same way that an online vendor has real-time visibility into customers who may place a product in an online shopping cart, a retailer with RFIDenabled smart shelves or smart carts can observe a shopper's initial purchase intention when they pick up or place a product in a cart. Knowledge of these preferences can be leveraged to sequentially price products so that, for example, a shopper who places a product in a cart can be offered a coupon for a substitute product (Aloysius et al. 2013).

In sum, the work in this stream points to a key theoretical and empirical gap: there is a need to develop a better understanding of auto-ID technologies, especially RFID, in shopper usage contexts.

\section{Technology Adoption, E-commerce, and Usability}

There is a vast body of research in IS on technology adoption (see Venkatesh et al. 2007; Venkatesh et al. 2012), e-commerce (e.g., Gu et al. 2012), and usability (e.g., Venkatesh and Ramesh 2006). The work in these interrelated streams has helped us gain a rich understanding of technology diffusion, e-commerce adoption, and even m-commerce adoption. Technology adoption research, which we will discuss in greater detail when we identify the outcomes of interest, has a rich tradition in IS research, with the technology acceptance model (TAM) emerging as dominant (see Venkatesh et al. 2007). E-commerce research has investigated the impact of product information and product reviews on customers' intentions to use e-commerce portals as well as 
their intention to purchase products (Forman et al. 2008). For instance, research has found that negative online reviews discourage customers from repurchasing products online (e.g., Cheung and Lee 2012). In addition, recent studies have extended this literature by investigating context-aware mobile applications and customers' willingness to receive product information and product reviews on their mobile phones independent of their location (e.g., Razzouk et al. 2008). Customers' privacy and control over mobile marketing notifications have been identified as one of the critical success factors of context-aware mobile applications (Cheung et al. 2005). Drawing on this stream and on usability research from IS and HCI, there have been some investigations of mobile applications and associated usability (e.g., Venkatesh and Ramesh 2006). Two broad ways in which prior work in this area can be classified are

(1) HCI research in the context of mobile applications, including application usability (see Adipat et al. 2011).

(2) Theory integration, with a focus on integrating mobile application-related factors into technology adoption theories (see Thong et al. 2011; Venkatesh et al. 2008; Venkatesh et al. 2011).

For instance, Adipat et al. (2011) studied the impact of interface structure on user performance and on user perceptions of mobile application interfaces. By manipulating task complexity and the presentation of mobile interface structure, they provided insights into the most effective mobile application interface structure. Usability constructs have also been integrated into existing theories, including TAM, to predict users' intentions to use specific mobile applications (e.g., Hess et al. 2005; Hong et al. 2007; Wells et al. 2011).

A synthesis of the literatures on technology adoption, e-commerce, and usability indicates that application content is one of the essential characteristics that distinguish successful e-commerce and m-commerce applications from less successful ones (Agarwal and Venkatesh 2002; Venkatesh and Agarwal 2006). Reviewing the literature on e-commerce and mobile applications, it becomes evident that product information and product reviews are content that play key roles in customers' purchase behavior (e.g., Forman et al. 2008).

Product information includes the presentation of any information that a shopper is seeking related to a product. Online shoppers value reading about products they are about to purchase as it helps them to make purchase decisions (Gu et al. 2012). Recent studies on mobile applications also indicate that product information is critical for customers' technology adoption in the context of mobile applications (e.g., Kowatsch and Maass 2010). This is due to the fact that customers appreciate reading additional product information on the spot when on shopping trips and looking for products in brick-andmortar stores. However, although e-commerce shoppers appreciate detailed product information, it is challenging to display on mobile applications. The more information that is provided on a mobile application, the more shoppers must navigate the mobile application and this in turn can negatively influence their perceptions of ease of use of a given mobile application (see Adipat et al. 2011). This can lead to a situation in which shoppers feel overwhelmed and face cognitive overload (see Shaft and Vessey 2006).

Product reviews include independent evaluations of a given product provided by buyers who previously purchased that particular product. Product reviews have become wellaccepted features of e-commerce applications and customers like reading reviews from peers and obtaining an independent evaluation of a product's reliability (Zhou et al. 2010). Recent studies on mobile applications in retail environments suggest that customers also appreciate product reviews when shopping in retail environments (Kowatsch and Maass 2010). In fact, many context-aware mobile applications focus on product reviews (e.g., restaurant rating apps) and shoppers can retrieve information that is tailored to their particular location (Kowatsch and Maass 2010). Although customers generally view product reviews as useful, extensive product reviews can lead to less user-friendly applications and shoppers might face cognitive overload (Zhou et al. 2010).

In this stream as well, there is a need for research on emerging technology artifacts leveraging auto-ID technologies and how these artifacts are perceived by customers based on their design and usability.

\section{Consumer Behavior}

Consumer behavior research has extensively examined the influence of product information and product reviews on customer attitudes and willingness to purchase a given product (e.g., Van Hoye and Lievens 2009). Many of these consumer behavior studies have investigated the potential impact of product information and product reviews on customers' shopping outcomes including convenience, word-ofmouth, customer service quality, and attitude toward a retailer (e.g., Bansal and Voyer 2000; Parasuraman et al. 1985). Specifically, past research has proposed the heuristic-systematic consumer processing model (Chaiken et al. 1989; Mahes- 
waran et al. 1992) that is relevant to how information obtained from an artifact in a retail environment might be utilized across different shopping contexts. Systematic processing occurs when customers consciously attempt to process and interpret information using thorough analytical thinking. In contrast, heuristic processing occurs when customers rely on limited, easily accessible information, such as prior beliefs and information available at the retail point of purchase, without considering additional information. Thus, systematic processing involves greater cognitive effort that would include use of more extensive product attribute information and evaluations that can be accessed using the artifact. However, the accessibility and processing of this more detailed information would potentially be more useful for higher involvement decisions (Petty et al. 1983) for higher-priced durables that are customer shopping goods (Kotler and Keller 2006). Heuristic processing is more typical for lower-priced convenience goods in which use of the artifact is less probable. In such judgments and decisions for these lowerpriced convenience products, the importance of a well-known brand name or brand image and equity may serve as a cue related to quality inferences and overall brand attitudes. Because relying on such cognitive shortcuts (heuristics) may not necessarily lead to optimal choices or well-informed product evaluations within any specific category, the artifact offers easy access to additional information that should aid in the customers' decision processes and impact outcomes. Compared to the traditional shopping experience, the artifact should reduce customers' search effort necessary to obtain information about products in which there is potential interest. The availability and use of this additional relevant and more detailed information obtained via the artifact should in turn positively impact perceptions of convenience, overall service quality offered by the retailer, and attitude toward the retailer by making the additional objective information easy to access.

As in the other two streams, given that consumer behavior studies traditionally have not focused on technology artifacts, such as auto-ID and mobile applications, none of these prior studies have linked auto-ID scanning technologies or mobile applications to key shopping outcomes.

\section{Design of Shopping Assistance Artifacts}

Our work follows the design science approach (e.g., Gregor and Hevner 2013; Gregor and Jones 2007; Moon and Ngai 2010) because our primary goal is to design and evaluate new technological artifacts. Specifically, we draw on Gregor and Jones' (2007) work that identified eight critical components of IS design science theory: (1) purpose and scope; (2) con- structs; (3) principle of form and function; (4) artifact mutability; (5) testable propositions; (6) justificatory knowledge; (7) principles of implementation; and (8) expository instantiation. We leveraged Gregor and Jones' framework to design the mobile shopping assistance artifacts and evaluate the artifacts in a retail environment.

The first component suggests that the purpose and scope of the designed artifact should be clearly articulated. In the early phase of our project, we focused on designing an artifact that helps practitioners address a current business problem in the retail industry. Our review of the practitioner literature suggested that retailers were exploring mobile scanning applications for shoppers to enhance the in-store shopping experience (see Angrisani 2013; Businesswire 2011; Wall Street Journal 2012). Due to the fact that most customers carry mobile smartphones during their shopping trips, retailers see an opportunity to provide content to customers via smartphones (e.g., product information or product reviews that are already available on retailers' websites) that customers may to be relevant during their shopping trips (Mobile Insider 2012). Based on this, we developed two prototype concepts of mobile application artifacts. The prototypes were to run on mobile smartphones, such as Apple's iPhone, and represented two alternative mobile applications that allow shoppers to either scan product barcodes via a barcode scanner or real RFID tags via a RFID reader in order to view product information and product reviews on mobile smartphones. A key goal of this exploratory investigation was to serve as an applicability check (see Rosemann and Vessey 2008).

The second component emphasizes constructs that represent the entities of interest in the artifact. As previously described, we turned to the academic literature to better understand the constructs most relevant to a designed technology artifact. It is also important to note that the interviews with practitioners also helped us identify the most critical concepts that practitioners wanted to better understand in the context of the shopping assistance artifacts. In particular, they signaled that they were interested in understanding critical factors influencing customers' adoption of the new technology, customers' security concerns, and how influential the shopping assistance artifacts would be for the overall customer-toretailer relationship. The constructs identified are discussed in the next section.

The third component focuses on the architecture that describes the artifacts being investigated. This component involves an abstract blueprint that describes the IS artifact. Two types of hardware designs are currently used in practice or considered for future use: barcode scanners and RFID 
Table 1. Hardware Design and Application Content Design

\begin{tabular}{|c|c|c|c|c|c|}
\hline None & \multicolumn{3}{|c|}{ Control group } & Advantages & Disadvantages \\
\hline \multirow{2}{*}{$\begin{array}{l}\text { Hardware } \\
\text { design } \\
\text { (different } \\
\text { content } \\
\text { served) }\end{array}$} & $\begin{array}{l}\text { Barcode } \\
\text { scanner }\end{array}$ & & $\approx$ & $\begin{array}{l}\text { Lower cost } \\
\text { International } \\
\text { standards (e.g., } \\
\text { GS1) }\end{array}$ & $\begin{array}{l}\text { Line of sight required } \\
\text { for data capture }\end{array}$ \\
\hline & RFID reader & & & $\begin{array}{l}\text { Line of sight not } \\
\text { required for data } \\
\text { capture }\end{array}$ & Higher cost \\
\hline \multirow{3}{*}{$\begin{array}{l}\text { Application } \\
\text { content } \\
\text { design } \\
\text { (both } \\
\text { hardware } \\
\text { designs } \\
\text { used) }\end{array}$} & $\begin{array}{l}\text { Product } \\
\text { information }\end{array}$ & \multicolumn{2}{|c|}{ 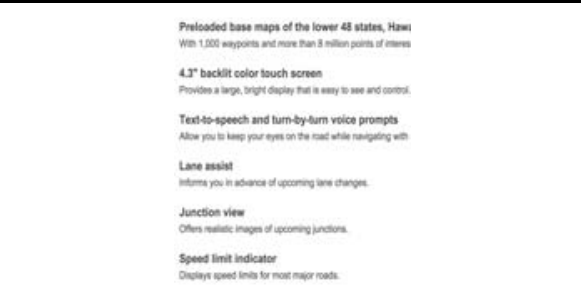 } & $\begin{array}{l}\text { Provides information } \\
\text { that may inform the } \\
\text { shoppers choice }\end{array}$ & $\begin{array}{l}\text { May have redundant } \\
\text { content already } \\
\text { available on package } \\
\text { or result in informa- } \\
\text { tion overload }\end{array}$ \\
\hline & Product review & \multicolumn{2}{|c|}{ 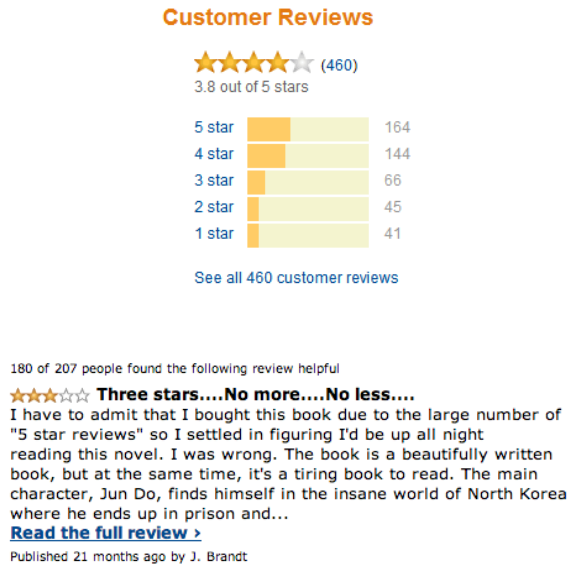 } & $\begin{array}{l}\text { Provides information } \\
\text { from user viewpoint } \\
\text { that may inform } \\
\text { shopper choice }\end{array}$ & $\begin{array}{l}\text { Trustworthiness } \\
\text { issues related to peer } \\
\text { reviews; would result } \\
\text { in information } \\
\text { overload }\end{array}$ \\
\hline & $\begin{array}{l}\text { Product } \\
\text { information } \\
\text { and product } \\
\text { review }\end{array}$ & 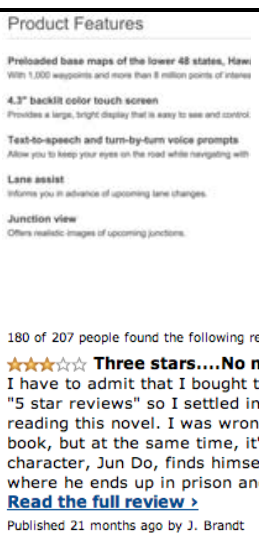 & 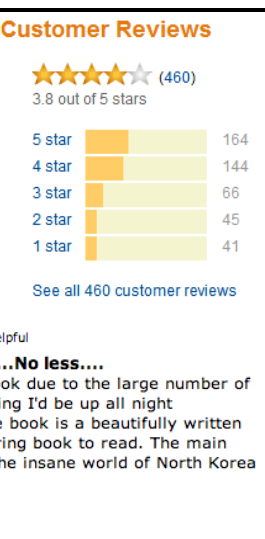 & $\begin{array}{l}\text { Information from } \\
\text { multiple independent } \\
\text { sources } \\
\text { (manufacturer and } \\
\text { users) that may } \\
\text { inform customer } \\
\text { choice. }\end{array}$ & $\begin{array}{l}\text { Increased information } \\
\text { overload and } \\
\text { potentially } \\
\text { contradictory } \\
\text { information as much } \\
\text { content may be } \\
\text { displayed on mobile } \\
\text { device screen }\end{array}$ \\
\hline
\end{tabular}


readers. For example, Stop \& Shop supermarkets and Walmart have conducted pilot tests in which shoppers used mobile phone applications to self-scan product barcodes (Businesswire 2011; Wall Street Journal 2012). There are also indications that in the near future there will be increasing interest in RFID-based applications for shoppers. Various apparel and footwear retailers, such as Macy's, Bloomingdales, JC Penney, and American Apparel, as well as some retailers in non-apparel categories, such as Walmart with its tires and electronics categories, have rolled out chain-wide item-level RFID tagging initiatives (Supply Chain Digest 2011). Thus, we configured artifacts with two mobile shopping hardware designs and three content designs, as shown in Table 1 . The hardware configurations involved a smartphone barcode scanner and smartphone RFID reader. Our motivation to integrate barcode scanning and RFID reading technologies into the shopping assistance artifact was influenced by the trade press (NFC World 2012; Reuters 2012; RIS Research 2012b), recent academic research (e.g., Bose et al. 2009; Ngai et al. 2008; Ngai, To et al. 2009), and our discussions with practitioners. Although both barcode and RFID reading technologies provide means for a data capture (of a specific product), enabling the display of information and/or reviews about that product, there is one substantive difference in their functionality. A barcode scanner requires the user to have optical line-of-sight to the barcode on the product and, therefore, the scanning device has to be aligned with the code for the data capture to occur. In contrast, RFID merely requires the reading device to be in the vicinity of the product (in the case of our experiment, the device had to be within 6 inches) and as long as there is no water or metal between the reader and the product, the data capture will occur. The content designs included product information, product reviews, and a combination of product information and product reviews. As with the hardware configurations, our content design configurations were influenced by practitioner reports (RIS Research 2012a), emerging academic interest in this area (Forman et al. 2008, Gu et al. 2012; Kowatsch and Maass 2010), and our discussions with practitioners. Recent research on product reviews has found reviews provided by retailers to be less trustworthy than product reviews provided by peers (Kowatsch and Maass 2010). This is partly driven by customers' perceptions that a retailer would delete extremely negative reviews to avoid losses in sales. Therefore, we exclusively provided product reviews from peers (i.e., customer reviews), and our application content design did not include any information provided by retailers.

The fourth component highlights that the design of the artifact should capture the dynamic of the phenomenon being studied. Retail environments are inherently complex and retailers' product databases and associated electronic storefronts are dynamically updated (e.g., when a customer posts a product review). We used product content that we downloaded from a major online retailer and we developed an application that displayed the content on shoppers' smartphones, such as Apple's iPhone. Although our application was not dynamically updated, ${ }^{4}$ retailers can adapt our static application to dynamic content by linking it to corporate databases. Thus, we believe the artifact is potentially mutable, and can be integrated into business operations and adapted to a variety of research contexts.

The fifth component relates to theory development, and indicates that researchers should demonstrate how and why the designed artifacts should lead to desired outcomes. Informed by the interviews with practitioners, we identified key outcomes relevant to the artifacts and developed theoretically motivated propositions for shoppers' perceptions and reactions to use of the mobile shopping assistance artifacts. The outcomes of interest are discussed in the next section, followed by the development of our propositions.

The sixth component focuses on the underlying knowledge from the natural, social, or design sciences that provide a basis and explanation for the design. We drew from existing literature to inform the design and development of our propositions. Given the novelty of the artifacts studied in our research, we felt this was particularly relevant for our proposition development, and we aimed to develop generalizations by observing patterns in the literature, our discussions with experts, and the findings from our experiments.

The seventh component includes a description of processes for implementing the artifacts or the theory in a specific context. As described earlier, we conducted an exploratory investigation with several experts in the retail industry. The feedback we received suggested that there is interest in leveraging mobile technologies to engage with retail shoppers. This was further supported by trade press reports indicating that leading retailers have pilot tested or implemented mobile barcode scanners in stores and were also considering RFIDbased mobile applications in stores. Thus, we found it reasonable to argue that our artifacts could be implemented in the context of retail stores. We will discuss both theoretical and practical implications for the implementation of mobile applications in a retail environment in greater detail when we discuss the findings of this study.

\footnotetext{
${ }^{4}$ A static application was required in order to maintain experimental control, as is explained in greater detail in the research design section.
} 
Table 2. Eight Components of the Information Systems Design Science Principles (adapted from Gregor and Jones 2007)

\begin{tabular}{|c|c|c|}
\hline \multicolumn{2}{|r|}{ Component } & Description \\
\hline & $\begin{array}{l}\text { Purpose and } \\
\text { scope }\end{array}$ & $\begin{array}{l}\text { Two alternative mobile applications that allow shoppers to scan tagged products in a retail } \\
\text { environment either via a barcode scanner or RFID reader. }\end{array}$ \\
\hline (2) & Constructs & $\begin{array}{l}\text { Based on academic literature and an applicability check conducted with practitioners, outcomes of } \\
\text { interest were identified (discussed later): } \\
\text { - } \quad \text { Technology adoption (intention to use, perceived usefulness, perceived ease of use); } \\
\text { - } \quad \text { Security beliefs (privacy concerns, trust, risk); and } \\
\text { - } \quad \text { Shopping (convenience, word-of-mouth, customer service quality, attitude toward a retailer). }\end{array}$ \\
\hline (3) & $\begin{array}{l}\text { Principle of form } \\
\text { and function }\end{array}$ & $\begin{array}{l}\text { The blueprint of the IT artifacts involved hardware and software designs: } \\
\text { - } \quad \text { Hardware design (smartphone barcode scanner and smartphone RFID reader directly } \\
\text { integrated into a smartphone); and } \\
\text { - Software design (application content included product information and product reviews as } \\
\text { well as a combination of both). }\end{array}$ \\
\hline (4) & Artifact mutability & $\begin{array}{l}\text { The artifact designs were developed with an eye toward scalability. Although our content was } \\
\text { static based on a major online retailer's product sites, a retailer's databases could be linked to the } \\
\text { artifacts. By having access to real-time data, the artifacts could adjust to the dynamic retail } \\
\text { environment. }\end{array}$ \\
\hline (5) & $\begin{array}{l}\text { Testable } \\
\text { propositions }\end{array}$ & $\begin{array}{l}\text { Six theoretically motivated propositions were developed across the three sets of outcomes } \\
\text { (discussed later). }\end{array}$ \\
\hline (6) & $\begin{array}{l}\text { Justificatory } \\
\text { knowledge }\end{array}$ & $\begin{array}{l}\text { Drawing on existing literature, generalizations were constructed from patterns observed in } \\
\text { literature and results from our experiments. }\end{array}$ \\
\hline (7) & $\begin{array}{l}\text { Principles of } \\
\text { implementation }\end{array}$ & $\begin{array}{l}\text { Several recommendations for implementing the theory in specific contexts were provided for both } \\
\text { artifacts. }\end{array}$ \\
\hline (8) & $\begin{array}{l}\text { Expository } \\
\text { instantiation }\end{array}$ & The mobile shopping artifacts were implemented in a realistic retail environment. \\
\hline
\end{tabular}

The eighth component focuses on the physical implementation of the artifact that can assist in testing propositions. We conducted two experiments in which participants evaluated the designed mobile shopping assistance artifacts. Both experiments required the physical implementation of the artifact. During our experiments, we did not encounter any major issues with the artifacts, nor did the participants encounter any major problems - no negative feedback or technical problems with the artifacts were reported. Table 2 summarizes the eight components of the design science principles in the context of our study. We discuss components 5 through 8 in greater detail later because they relate to the proposition development and findings of our studies.

\section{Outcomes of Interest}

We turn both to research and practice to inform our selection of outcomes of interest for our study of the effects of our shopping assistance artifacts. First, given our technology context, the earlier discussion on the mature stream of technology adoption provides a relevant base of constructs that could serve as important metrics of comparison across different competing artifact designs. From a practical perspective, comparing technology adoption outcomes will shed light on the preferred artifact design(s). Second, both from a technology perspective and from a customer perspective, concerns around security of customers' information in terms of browsing behavior, product choices, purchases, and credit/ debit card information has become a source of worry among customers, especially with stories of identity theft being rampant in the trade press (for a discussion, see Belanger and Crossler 2011; Smith et al. 2011). This is reinforced by a substantial body of research, both in IS and marketing, pointing to the importance of various constructs related to security in driving customers' channel choice (Kim et al. 2009). Finally, in any shopping situation, especially with changes in the retail environment, such as what happened when e-commerce was introduced over a decade ago, relevant outcomes from consumer behavior research will be important to understand, as they will complement the more technology-centric focus of IS research. Together, these three sets of outcomes can help us gain a holistic understanding of the impact of the technology artifacts. 


\section{Technology Adoption Outcomes}

Individual-level technology adoption research is one of the most mature streams in IS (Venkatesh 2006; Venkatesh et al. 2007). In this stream, there are several key predictors that have been used in a variety of contexts as a gauge for success of new systems. More recently, technology adoption has been studied in e-commerce settings where customers interact typically with websites and purchase products online (e.g., Adipat et al. 2011; Chiu et al. 2014; Venkatesh and Agarwal 2006). In the emerging body of literature on mobile commerce (mcommerce), technology adoption studies have examined factors influencing customers' motivations to use mobile banking (Mallat 2007), mobile Internet (Hong et al. 2006), and/or mobile payments (Mallat 2007).

In this body of work, intention to use has played a critical mediating role between customer beliefs and ultimate behavior (e.g., Brown and Venkatesh 2005). In cases where the behavior is new or yet to be performed, intention is even more critical as a proxy (see Venkatesh et al. 2006). There is a significant amount of RFID and mobile application research that studied perceived usefulness and perceived ease of use in the context of these emerging technologies (Kim and Garrison 2009). Perceived usefulness is defined as the degree to which using a technology provides benefits to customers in performing certain activities and perceived ease of use is the degree of ease associated with customers' use of technology (see Venkatesh et al. 2012). We thus study technology adoption outcomes as a key set of dependent variables. Specifically, we examine intention to use, perceived usefulness, and perceived ease of use-all related to the specific shopping assistance artifacts. In our context, theorizing and comparing the effects of different technology artifacts on intention to use, perceived usefulness, and perceived ease of use related to competing shopping assistance artifacts will contribute to the understanding of their potential success.

\section{Security Beliefs Toward Shopping}

In the context of technology-mediated shopping, issues surrounding shoppers' perceptions of security can play a critical role in driving customers' views about e-channels (Kim et al. 2009; Pramatari and Theotokis 2009). This is underscored in the IS and marketing literatures by a significant amount of work related to customer perceptions of privacy, trust, and risk, especially in e-commerce settings (e.g., Belanger and Crossler 2011; Hoehle et al. 2012; Kim et al. 2009; Lowry et al. 2008). It has been demonstrated that trust and risk play critical roles in customer decisions (Chiu et al. 2014) because customers now have an unprecedented level of exposure of their personal information. Related to this, given customer information being exposed due to the use of technology and given the layers of intermediaries who have access to their information, privacy of customer information has also become vital-in practical terms, customers experience this via extensive privacy policies to which they have to agree (or not be able to conduct a transaction online). Further, in practice, we have witnessed a great deal of identity theft, stolen accounts, and other security violations with online stores (e.g., Warkentin and Willison 2009). With mobile devices being used for shopping-on-the-go and shopping in-store, customer perceptions of security will become even more important (Luo et al. 2010). To this end, we examine shopper perceptions related to security via three key constructs: privacy concerns, trust, and risk.

We define privacy concerns as "a desire of individuals to control or have some influence over data about themselves" (Belanger and Crossler 2011, p. 1017). With the advent of e-commerce, privacy became an increasingly important issue for the retail industry due to the fact that personal information can be easily collected, stored, processed, and used by multiple parties (Belanger and Crossler 2011; Smith et al. 2011). Not surprisingly, much research has followed practice and studied the concept in various fields, such as IS (Belanger and Crossler 2011; Razzouk et al. 2008), marketing (Rust et al. 2002), and psychology (White 2004). In IS, researchers have studied privacy in various contexts, such as organizational privacy concerns, e-business impacts of privacy, and customers' attitudinal beliefs about privacy (Belanger and Crossler 2011; Pramatari and Theotokis 2009; Thiesse 2007). Salient to this research, an individual's perceptions of and reactions to invasive technologies, such as instant messaging on mobile phones and RFID, have been studied (e.g., Thiesse 2007). These articles emphasized that customers are concerned about their privacy if they learn that organizations collect personal information about themselves. Further, privacy concerns of individuals related to RFID have been amplified by negative media coverage regarding RFID. A literature review of trade press articles on RFID (see Thiesse 2007) found that most were related to privacy issues.

Trust can be defined as "the belief that the vendor will act cooperatively to fulfill the customer's expectations without exploiting their vulnerabilities" (Pavlou and Fygenson 2006, p. 123). It is well documented that individuals' trust perceptions in a technology play an important role in whether individuals accept and use technologies, such as e-commerce portals (Gefen et al. 2003). Researchers have used various theories, such as TAM and the theory of planned behavior (TPB; Ajzen 1991), in conjunction with trust constructs to explain e-commerce at the individual level (e.g., Gefen et al. 2003; Pavlou and Fygenson 2006). For example, Gefen et al. (2003) integrated a trust construct into TAM and found that 
trust was a driver of perceived usefulness and customers' intentions to use Amazon's e-commerce application. Similarly, Pavlou and Fygenson (2006), using TPB, found that trust would be an important predictor of customers' attitudes toward electronic commerce applications.

Risk is defined as a customer's "concerns about whether the selling party will violate its formal and informal obligations, for instance by violating confidentiality norms, product quality or delivery commitments” (Kim et al. 2009, p. 241). Much e-commerce research has found that risk is a major source of customers' resistance to purchase products online. In an e-commerce context, customers always experience some level of risk because they purchase products from retailers who are geographically dispersed and products are purchased sight-unseen. Risk will negatively influence customers' intentions to purchase products on a given e-commerce platform. Research has also found that the concepts of trust and risk are interrelated and individuals who have high levels of trust in a selling party will perceive a low likelihood that the selling party will violate transactional obligations (Kim et al. 2009).

\section{Customers' Shopping Outcomes}

There are a number of shopping outcomes that could be studied in various shopping contexts. We chose four widely studied outcomes in the field of consumer behavior because of their theoretical importance and potential implications for retailers. The outcomes we chose were: convenience (Brown 1989; Seiders et al. 2000), word-of-mouth (Bansal and Voyer 2000), service quality (Zeithaml, Berry, and Parasuraman 1988; Zeithaml, Parasuraman, and Berry 1985), and attitude toward the retailer (Morschett et al. 2005).

Convenience is defined as the time and effort customers use in purchasing a product (Brown 1989; Kelley 1958). The importance of shoppers' perceptions of shopping convenience and its effects on retailer evaluations has long been of interest to consumer behavior researchers (e.g., Kelley 1958; Seiders et al. 2000; Seiders et al. 2005). Retailers understand that it is critical to enhance the convenience of the overall shopping experience, given that convenience is linked to customer satisfaction and intentions to shop the store in the future, as well as the overall attitude toward the shopping experience (e.g., Jih 2007).

Word-of-mouth is defined as "an interpersonal communication, independent of the organization's marketing activities, about an organization or its products" (Van Hoye and Lievens 2009, p. 342). A large body of consumer behavior research has studied the pervasive impact of word-of-mouth on customer beliefs and behavior (Bansal and Voyer 2000). In contrast to commercial advertisements and organizational marketing campaigns, word-of-mouth is generated by individuals who have no self-interest in promoting a given product or retail store and thus may be perceived as providing highly credible information (Van Hoye and Lievens 2009). Of salience to this research, word-of-mouth can be communicated through all sorts of technologies including the Internet or mobile applications (Van Hoye and Lievens 2009). Further, it is important to recognize that shoppers can provide word-of-mouth information to diverse audiences, including family, friends, colleagues, and even complete strangers (Van Hoye and Lievens 2009). Also, word-of-mouth can occur coincidently or can be based on specific reactions of the shopper, for example, satisfaction or dissatisfaction with a store experience (Van Hoye and Lievens 2009).

Service quality is defined as the customers' overall impression of the relative inferiority/superiority of the service provided by an organization (Bitner and Hubbert 1994), and has been a crucial topic in retailing and consumer behavior research for decades. For example, Zeithaml, Berry, and Parasuraman (1988) and Zeithaml, Parasuraman, and Berry (1985) assessed various dimensions related to service quality and their effects on customer outcomes. Although there has been considerable debate regarding the most appropriate conceptualization and measurement of customer perceptions of service quality in general, we address quality aspects related to the specific use of the mobile device for retail shopping (Yoo et al. 2000). Thus, in this context, both the mobile shopping assistance artifact that can be used at the retail point-of-purchase and the broader information provided through customer reviews and product information are viewed as extending the service environment that the retailer provides for its shoppers.

Attitude toward a retailer is defined as the predisposition of a shopper to respond in a favorable or unfavorable manner to the retailer (Ajzen 1991; Morschett et al. 2005). This attitudinal construct is a global evaluation of the retailer that in this context is potentially influenced by the use of the technology and the type and amount of information that can be easily accessed at the point-of-purchase (Elliott and Speck 2005). This overall evaluation becomes crucial to retailers in a highly competitive marketplace in which ways to differentiate the organization from primary competitors is important (Morschett et al. 2005).

\section{Proposition Development}

We develop our propositions in this section as follows. First, we theorize about the effects that different hardware artifacts 


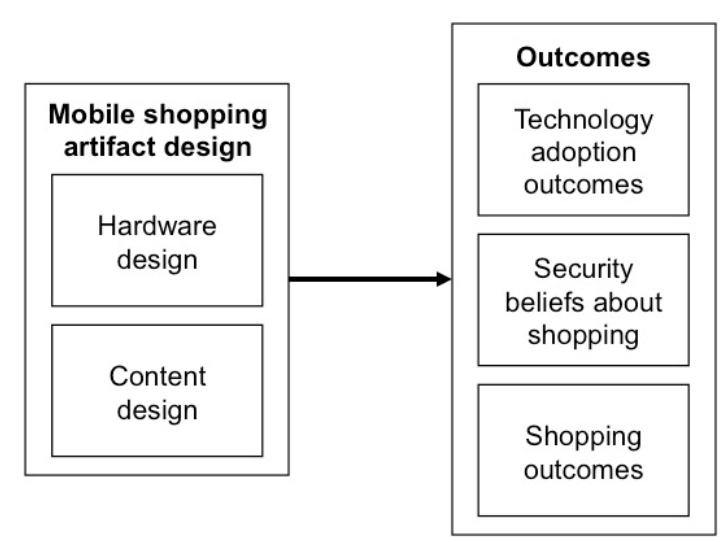

Figure 1. Conceptual Framework

(i.e., barcode scanner versus RFID reader) in mobile in-store shopping will have on the three sets of outcomes: technology adoption outcomes, security beliefs toward shopping, and shopping outcomes. Second, we theorize about the effect that content design (product information versus product reviews versus both) in mobile in-store shopping will have on the same outcomes. Figure 1 shows the design elements that we manipulate and the outcomes on which we expect them to have an impact.

\section{Hardware Design}

A barcode scanner on a mobile phone is a technological design feature that many retailers are starting to make available to their customers and testing in the store (Reuters 2012). Some retailers have also begun to explore the possibility of RFID-based read applications in the hands of shoppers (NFC World 2012). As we discussed earlier, one advantage of RFID readers, in comparison to barcode scanners, is that it is not necessary to have optical line-of-sight to read a tag. The requirement of optical line-of-sight adds a step for a shopper to seek product information, as they need to physically position/reposition either the scanning device or the product being scanned, or both. Even such a single additional step can negatively affect usability, which typically incorporates perceptions of both usefulness and ease of use, and is particularly salient when it comes to applications on mobile devices (see Kim and Garrison 2009; Venkatesh and Ramesh 2006). In addition to the extra step when using a barcode scanner, there is the element of quicker and easier access to information when using an RFID reader compared to a barcode scanner because the application content is updated automatically and no manual intervention is required (i.e., physical act of scanning does not have to be performed). From a tech- nology adoption perspective, additional steps and lower speed of access increase the effort involved in using a barcode scanner compared to an RFID reader (see Kim and Garrison 2009; Venkatesh et al. 2011) and can negatively affect perceived ease of use that in turn is a known determinant of perceived usefulness because efficiency can positively affect effectiveness (Venkatesh 2000; Venkatesh and Davis 2000). The perceptions of usefulness will also be lower for a barcode scanner because the amount of information that a shopper accesses (and consequently uses) when using a barcode scanner will be substantially less than what he or she can obtain when using an RFID reader. This is consistent with a vast body of research in a variety of settings that has demonstrated that perceptions of usefulness and ease of use together determine intention to use a technology (Venkatesh et al. 2007; Venkatesh et al. 2012). As intention represents the overall assessment toward the technologies in question, with favorable perceptions of usefulness and ease of use, intention to use an RFID reader can be expected to be more favorable when compared to intentions to use a barcode scanner. Thus, we theorize

Proposition 1: Shoppers with an RFID reader will have more favorable technology adoption outcomes than shoppers with a barcode scanner. ${ }^{5}$

Privacy concerns influence attitudes and intentions, and include the collection of data, unauthorized secondary use of data, and improper access to data and errors in data (Smith et al. 2011). In comparison to unassisted shoppers, who have no

\footnotetext{
${ }^{5}$ The perceived usefulness and perceived ease of use constructs pertain to the technology, and because unassisted shoppers, by definition, do not use the shopping assistant artifact, these constructs are not relevant to unassisted shoppers.
} 
reason to believe that their shopping and browsing behavior is being monitored or have adjusted to the current level of intrusions and risks, shoppers using a mobile device with a barcode scanner know that, when they scan a product, the information may be collected by the retailer. Shoppers' beliefs about unauthorized use and improper access will be minimal in the case of unassisted shoppers if they do not believe that the data are being collected. Therefore, we expect that shoppers with barcode scanners will have greater privacy concerns than unassisted shoppers will. The act of scanning barcodes is voluntary because it takes a specific, deliberate action by the shopper for a data capture to occur. Thus, any information captured (e.g., a shopper's interest in a product) occurs with the knowledge and consent of the shopper. An RFID reader, however, may read a product automatically, because mere proximity to a tag is sufficient for a read. Thus, shoppers may believe that as they walk through the aisles, it is possible that an RFID reader may initiate an automatic read. We argue that shoppers using RFID readers will consequently have heightened privacy concerns (i.e., they will involuntarily reveal information), given the increased possibility of data errors in the form of involuntary scans, as well as concerns about unauthorized use and improper access (Pramatari and Theotokis 2009; Ramos et al. 2009). Privacy concerns have been shown to negatively impact trust and increase risk perceptions (Olivero and Lunt 2004). Specifically, individuals who are concerned about privacy are often concerned about the risk involved in e-commerce transactions because they view this medium as less trustworthy. Due to privacy concerns, we expect that RFID will erode shopper trust in the shopping process. This argument is echoed by prior researchers who have investigated and demonstrated RFID-related privacy concerns (Beitelspacher et al. 2012; Wu et al. 2012). RFID has also been shown to be associated with perceptions of privacy risk likelihood and privacy risk harm (Cazier et al. 2008). Thus, we theorize

Proposition 2: Shoppers with an RFID reader will have the least favorable evaluations of security beliefs toward shopping followed by shoppers with a barcode scanner, and followed by unassisted shoppers.

Seeking product information is effortful for an unassisted shopper. Getting such information involves picking up the product, searching the packaging on all sides, and trying to make inferences based on the limited information provided, and is not easy. Use of mobile shopping assistance artifacts may increase the perceived convenience of the shopping experience of the customer. In comparison, accessing such information with a barcode scanner is comparatively quicker and easier because the information is laid out in a page format optimized for viewing, as opposed to fitted on different parts of the packaging in a manner that does not interfere with the aesthetic visual appeal of the package design. Furthermore, the electronic content may contain more information than is practically possible to fit on the package, especially for smaller products. An RFID reader makes the customer information search task even quicker and easier, as it accomplishes the same purpose as a barcode scanner without the additional requirement that the scanner should have optical line-of-sight. Because both time and effort perceptions are used to characterize convenience (Berry et al. 2002), we expect that shoppers will experience greater convenience with an RFID reader in comparison to a barcode scanner that will in turn provide greater convenience than an unassisted shopper will experience. Among other factors, access to information, responsiveness to information search, and perceived ease of use have been identified as key dimensions of online retail service quality (Jun et al. 2004). Given that the barcode scanners and RFID readers enable access to information and also accentuate information search (Parasuraman et al. 1988), we expect shoppers using either of the two hardware designs will have higher service quality perceptions than unassisted shoppers will. We believe that an RFID reader will facilitate browsing to a greater degree and facilitate obtaining greater breadth of information than a barcode scanner, and this will result in the shopper finding a greater number of products with an RFID reader compared to when using a barcode scanner. Because of this, we expect that shoppers with an RFID reader will perceive higher service quality perceptions than shoppers with a barcode scanner will. Thus, we theorize

Proposition 3: Shoppers with an RFID reader will have the most positive shopping outcomes followed by shoppers with a barcode scanner, and followed by unassisted shoppers.

\section{Application Content Design}

Application content design includes product information and product reviews that are displayed on the shopping assistance artifacts. Prior studies on e-commerce have found that customers' adoption behavior toward e-commerce applications will increase if e-tailers provide additional product information and product reviews. Customers would be encouraged to use the application if they found information they seek related to the products they are about to purchase or research online (Forman et al. 2008). Likewise, studies on context-aware mobile applications suggest that customers welcome having access to product information (e.g., a restaurant menu) as well as access to product reviews (e.g., reviews related to prior experiences from peers with the restaurant). This would provide them with a sense of reliability regarding the product and services they are about to buy, which would 
lead to increased adoption of the mobile application. The more product information is available regarding products that customers are about to purchase, the more useful customers view the application that in turn will lead to higher adoption of the application. Effective content design of mobile applications allows customers viewing a considerable amount of information on smartphone displays. Instead of presenting a large body of text, mobile application usability research suggests that it is important to carefully select only the most critical information users want for the mobile application. This way, users would not face information overload and the mobile application would become easy to use. Consequently, a well-designed interface that includes both product information and reviews will be perceived to be easier to use than presenting only one type of content because having more information will enhance a shopper's ability to shop more efficiently. Based on the arguments, we expect that effective content design will have a positive effect on technology adoption outcomes. Specifically, we suggest that shoppers will favor having access to product information and product reviews rather than having only one type of information (e.g., only product information). This is consistent with e-commerce research suggesting that product reviews provided in combination with product information will result in higher online sales (Forman et al. 2008). Based on prior studies on e-commerce (e.g., Gu et al. 2012; Susarla et al. 2012), we further propose that product reviews will have a more positive effect on technology adoption outcomes than product information will. This is due to the fact that product reviews are viewed as more valuable because peers, who have no interest in positively biasing the content presented on the mobile application, provide the product reviews. Thus, we theorize

\section{Proposition 4: Shoppers provided with product information in combination with product reviews will have the most favorable technology adoption outcomes followed by shoppers provided with product reviews followed by shoppers provided with product information followed by unassisted shoppers.}

There is a substantial amount of research that has studied the effect of content design on customers' security perceptions of e-commerce applications (Kim et al. 2009; Lowry et al. 2008). In general, additional information related to products and the selling party positively influences customers' security beliefs because customers can learn about the product features, payment procedures, and delivery processes (Gefen et al. 2003). The more product information is available online, the more trustworthy the selling party is generally perceived to be and, therefore, customers would view it as more secure to purchase products from such an e-tailer.
Likewise, prior studies found that customers' trust toward e-commerce portals increases if they have access to product reviews ( $\mathrm{Li}$ and Hitt 2010). These product reviews can be either provided by independent reviewers (i.e., peers) or, alternatively, by retailers providing a shopping assistant application for customers. Both forms of product reviews would increase customers' trust levels as it would attest to the quality of a given product. Recent studies have shown that peer reviews would be particularly trustworthy from a customer's perspective (Li and Hitt 2010) because these independent reviewers have no interest in promoting or downgrading a given product. Likewise, shoppers can learn that the seller has fulfilled the customer expectations in prior sales transactions when peers provide reports of their experiences with a given retailer (Gefen et al. 2003). Product reviews would also be useful for obtaining information regarding prior privacy violations because customers often report negative experiences, such as data security breaches that violate their privacy. ${ }^{6}$

Based on this, we expect that effective content design will have a positive effect on shoppers' security beliefs in the context of the newly designed shopping assistance artifact. In particular, we believe that shoppers' security beliefs will be influenced such that the more content that is provided on the mobile application, the more secure shoppers will feel (Luo et al. 2010). Product information is the most basic form of content that can be provided on a mobile shopping application. Although we expect that product information will have a positive effect on customers' security beliefs toward shopping, we expect the positive effect of product reviews to be even stronger. Product reviews written by independent peers who have no interest in selling additional products to customers will likely contribute more favorably to shoppers' security beliefs than product information will. We also propose that product information in combination with product reviews will have the most positive effect on security beliefs because it provides customers with two alternative information sources (i.e., e-tailer and independent sources). These independent sources will corroborate the product information displayed that will together have a positive effect on shoppers' security beliefs. Thus, we theorize

Proposition 5: Shoppers provided with product information in combination with product reviews will have the most favorable security beliefs followed by shoppers provided with product reviews

\footnotetext{
${ }^{6}$ One example of such a security breach is Sony's data security breach that occurred in 2011. During this breach, 77 million customer accounts were hacked and customer data, including customers' credit card information were stolen. As a result, many affected customers posted negative product reviews on various online review sites (Sherr and Wingfield 2011).
} 
followed by shoppers provided with product information followed by unassisted shoppers.

Prior e-commerce literature suggests that customers view product information and product reviews as a convenient way to research products and information on e-commerce portals (Mudambi and Schuff 2010; Senecal and Nantel 2004). Depending on the content provided by an e-commerce portal, customers can conveniently read product information in combination with product reviews. Alternatively, depending on their preferences, they can decide to focus on one information source (e.g., product reviews) and choose the most relevant information source for their needs. Having access to multiple information sources will generally lead to more positive attitudes toward retailers (Mudambi and Schuff 2010; Senecal and Nantel 2004) because customers appreciate retailers for providing them with a choice for seeking trustworthy information related to the products they are about the purchase. Likewise, research on customer service quality in the context of e-commerce has established that customer service quality increases if shoppers are provided with product reviews. Finally, research on consumer behavior and e-commerce has found that detailed information has a positive impact on wordof-mouth activities (Chan and Ngai 2011; Van Hoye and Lievens 2009). We thus propose that effective content design will have a positive effect on customers' shopping outcomes. A combination of product reviews and product information provided on a shopping assistance artifact will have the most positive effect on customers' shopping outcomes. This is due to the fact that shoppers will appreciate having the option to access and utilize both product reviews and product information. Prior work shows that shoppers show positive reactions toward product information that sellers provide them (see Duan et al. 2008). Likewise, shoppers will appreciate having access to product evaluations from previous buyers (see Srinivasan et al. 2002). Thus, we propose that alternative information sources related to products (i.e., product information and product reviews) will have a positive effect on customers' shopping outcomes.

Product reviews are independent of the seller and manufacturer, and shoppers view these evaluations as honest, unbiased feedback (Forman et al. 2008). In contrast, product information may be perceived as offering content that is included by the seller or producer to increase sales, which can be viewed negatively by shoppers as the content appears unrealistically positive (Duan et al. 2008). In addition, product information is the most basic level of information that can be provided as part of mobile shopping application content. Thus, based on prior research on consumer behavior and e-commerce (e.g., Gu et al. 2012; Susarla et al. 2012), we suggest that product reviews will have a more positive effect on customers' shopping outcomes than product information will. Yet, we propose that product information will still have a more positive effect on customers' shopping outcomes compared to an unassisted scenario because it provides information that helps shoppers evaluate specific products of interest. Thus, we theorize

Proposition 6: Shoppers provided with product information in combination with product reviews will have the most favorable shopping outcomes followed by shoppers provided with product reviews followed by shoppers provided with product information followed by unassisted shoppers.

\section{Method}

We conducted two studies in a retail store laboratory to test our propositions. The two studies varied in terms of the type of customer task (i.e., general browsing and shopping versus goal-directed shopping) in order to assess the generalizability of our theory to these two major types of shopping contexts.

\section{Participants and Measurement}

Participants were recruited from a mailing list maintained by the retail laboratory where the studies were conducted and the list was used to locate participants for customer studies. The participants were recruited via a targeted e-mail to customers who had specifically agreed to be on a mailing list to receive promotions and advertisements from retail stores. The list was organized to have representation and diversity in terms of different demographic characteristics, such as gender, age, income, race, educational background, and technology experience. The e-mail requested them to visit a new store set up and provide feedback/reactions. They were asked to plan for 60 to 90 minutes to participate in a study examining a new store design and to fill out a 30-minute survey about their experiences. We offered no financial or other incentives to participate in the study. We sought to have at least 30 participants in each of seven cells- one unassisted and each of six combinations of hardware design and content design. We had a total of 227 participants in study 1 and 221 participants in study 2 . The participants were split about equally between women and men, with an average age of 34.8 and a standard deviation of 8.5. In both studies, there were no significant differences across the different cells in terms of demographic characteristics. Appendix A summarizes the respondent demographics.

We adapted existing scales to operationalize the constructs used in our study; the items and sources are shown in Appendix B. 


\section{Setting, Treatments, Tasks, and Data Collection Procedure}

The retail store laboratory was designed to appear similar to a retail store in its layout and was set up as a mock storefront for "Acme Products." Specifically, products were placed on both sides of each of four shopping aisles, with each aisle being 300 feet long. A total of 100 product categories and 400 different products, including electronics, cleaning supplies, books, GPS navigation systems, CDs, and DVDs, were distributed across these aisles, and specific arrangements (aisles, products on shelving, end caps, etc.) were created to give a realistic store look. Product categories (e.g., books, GPS navigation systems, CDs) were clustered in designated areas and signposts were used as a guide for the participants. The design of the retail store laboratory aimed to ensure that the research context and environment were realistic as a way to increase the external validity of the controlled experimental studies. Upon entering the retail store laboratory environment, each participant met with an individual, who was not directly involved in the study and was given a set of instructions. Each participant was given 500 “Acme Dollars” to spend in the store. In both studies, participants were instructed to shop in the simulated retail store environment and told to feel free to walk around the store as they would in an actual retail shopping trip. In the experimental conditions, participants in each study were provided with an iPhone5 and instructions that related to the availability of apps (i.e., either a barcode scan app or an RFID read app). For example, in the RFID condition, they were told that the app "would allow you to obtain product information (e.g., product information, product reviews) if you place it within 6 inches of the product," and to feel free to "use this app to aid you in your browsing and shopping." In the barcode condition, they were given the same instructions - that is, "the phone has an app that will allow you to scan product barcodes and get product information (e.g., product information, product reviews)," and to feel free to "use this app to aid you in your browsing and shopping.” In all experimental conditions, the participants were also given a demonstration on the use of the artifact. In the control condition, in which the aid of the shopping assistance artifact was not provided, participants received the exact same instructions, but they were not provided with any information related to the phone or information-related apps.

With an eye toward generalizability or to understand possible differences across two different, major types of shopping tasks (i.e., general browsing and shopping versus goaldirected shopping), we conducted two experiments. Although the experimental design and retail store laboratory setting were identical across both studies, the context of the two studies differed. In the first experiment, the shoppers were allowed to browse through the retail shopping environment without a specific predetermined goal to shop for a specific product (Bloch et al. 1986). This permits a search context in which shoppers may utilize the technology to gather information that is independent of a current need within a specific category (i.e., this is consistent with the retail browsing and customer shopping motivations literatures) (see Bloch et al. 1989). However, although no categories were specified, participants were instructed to "choose at least five products that you would like to buy." In the second experiment, the shopping task was altered. Shoppers were asked to make a choice among alternatives in a specific predetermined category (i.e., a portable GPS navigation system) in which there were several brands with different features available. All GPS navigation systems were displayed in a designated area in the retail store. As mentioned earlier, all areas were signposted in order to guide shoppers to areas within the retail store. This more focused task is consistent with goal-directed shopping (Krantz and Kunreuther 2007; Van Osselaer and Janiszewski 2012) in which the shopper must construct brand evaluations and make choices within product categories that are prespecified prior to the retail shopping trip (i.e., the shopper is visiting the retailer to buy a specific product) (e.g., Shocker et al. 1991). Thus, the two experiments differed based on the shopping tasks presented to the participants.

Consistent with the artifact design discussed earlier, participants in our treatment conditions were exposed to one of two different hardware designs and one of three different content designs. The hardware design was varied by providing either a barcode scanner or an RFID reader (which was an attachment to an iPhone). These hardware designs were consistent with the emerging technologies in the marketplace and with some stores, such as Stop \& Shop and Walmart, currently testing mobile phone barcode scanners for shopper use in-store. An RFID-based read application on a smartphone is another such emerging technology (NFC World 2012). Content design was varied by providing different types of content details regarding products: product information versus product reviews versus both product information and product reviews. The product information and/or product reviews were uploaded to the device by obtaining the actual product information and product reviews from a major retailer's online store site. The first condition provided product information akin to what is typically available in an online store. The second condition provided product reviews in the form of ratings and comments from other customers. The third condition provided both product information and product reviews. A participant in the barcode scanner condition needed to line up the barcode scanner with the barcode on the product packaging to access the product information and/or reviews. A participant in the RFID reader condition merely needed to hold the device within close proximity (within 6 inches or so) of the product. In each case, the rele- 
Table 3. Experimental Design and Sample Sizes

\begin{tabular}{|c|c|c|c|c|c|}
\hline & \multicolumn{4}{|c|}{ Content Design } \\
\hline & & None & $\begin{array}{c}\text { Product } \\
\text { Information }\end{array}$ & Product Review & $\begin{array}{c}\text { Product } \\
\text { Information and } \\
\text { Review }\end{array}$ \\
\hline \multirow{3}{*}{$\begin{array}{l}\text { Hardware } \\
\text { design }\end{array}$} & None & $33 / 31$ & NA & NA & NA \\
\hline & Barcode scanner & NA & $31 / 34$ & $30 / 30$ & $34 / 32$ \\
\hline & RFID reader & NA & $35 / 31$ & $31 / 31$ & $33 / 31$ \\
\hline
\end{tabular}

Note: Cells contain sample sizes: study 1/study 2 .

vant information (product information, product reviews, or both) appeared on the screen. Our experimental design therefore was 2 (hardware design) $\times 3$ (content design) in addition to a control condition. From the perspective of the hardware design conditions, the participants were assigned randomly to content designs; from the perspective of the content design conditions, the participants were assigned randomly to hardware design conditions. The control condition was traditional unassisted shopping, where participants would perform the task assigned without the aid of any shopping assistance artifact. Table 3 shows our study design and the sample size in each cell in each of the two studies. Note that if some hardware is used, content must be served (otherwise the hardware is meaningless); likewise, for some content to be served, some hardware must be used (otherwise the content cannot be served). Because the RFID/barcode usage in our experiments were concrete manipulations (i.e., there were no latent, higher-order constructs manipulated), manipulation checks were not deemed necessary (see Perdue and Summers 1986, p. 317; Redden and Hoch 2009; Wilcox et al. 2009).

As noted earlier, our target was to have at least 30 participants in each cell; therefore, we assigned about 35 participants to each cell to allow for participants to withdraw from the study, incomplete responses, and unusable responses for other reasons (filling out all 1s or 7s). The participants were told that they had up to 45 minutes to complete the shopping task in experiment 1 and 30 minutes to complete the task in experiment 2. Following the completion of the shopping task, they filled out a survey about their perceptions of the entire shopping experience.

\section{Results}

Prior to discussing the results of our hypothesis testing, we make observations about the patterns of participant behavior in our studies. The overall average time that the participants spent in our retail store laboratory was 34 minutes and 24 minutes in experiments 1 and 2, respectively. Interestingly, the unassisted shoppers in both cases spent the least amount of time, whereas the users of the RFID reader spent the most time followed by the users of the barcode scanner. It seems reasonable to argue that this was triggered by the additional product information to be processed by participants with shopping assistance devices compared to those without shopping assistance devices. In terms of content design, those in the combined product information and review condition spent the most amount of time. This was likely due to the novelty of the hardware design and the comprehensiveness of the content being served. The users of the barcode scanner scanned an average of 12 products and the users of the RFID readers read an average of 23 products. This was despite the fact that the participants used both technologies voluntarily. There were no substantial variations in terms of number of products scanned by those provided with different content. The participants took about 25 minutes to complete the survey which included several additional questions that served as fillers from the perspective of this research.

We first examined the reliability and validity of our scales. Cronbach alphas were greater than .80 for all scales in each cell. With the data in each study (aggregated across conditions due to sample size issues), we ran a factor analysis with direct oblimin rotation to allow for correlated factors and found that loadings were greater than .70 and cross-loadings were lower than .35, thus supporting internal consistency and discriminant validity. Overall, this suggested that the scales were reliable and valid in our context. These results are not shown here due to the clean pattern.

As explained earlier, we identified constructs relevant to the context of our study and clustered them into three distinct groups: (1) technology adoption, (2) security beliefs, and (3) shopping. In order to analyze the findings related to the three groups of constructs, we map our propositions to specific constructs to present testable hypotheses. For example, proposition 1 suggested that hardware design will have a positive effect on technology adoption outcomes. The 


\begin{tabular}{|c|c|c|c|c|c|c|c|c|}
\hline \multirow[b]{3}{*}{ Outcomes } & \multirow[b]{3}{*}{ EXPERIMENT 1} & \multirow{2}{*}{\multicolumn{2}{|c|}{$\frac{\text { (1) Unassisted }}{\mathrm{N}=33}$}} & \multirow{2}{*}{\multicolumn{2}{|c|}{$\begin{array}{c}\text { (2) Barcode } \\
\text { scanner } \\
\mathrm{N}=95 \\
\end{array}$}} & \multirow{2}{*}{\multicolumn{2}{|c|}{$\begin{array}{c}\text { (3) } \mathrm{RFID} \\
\text { reader } \\
\mathrm{N}=99 \\
\end{array}$}} & \multirow[b]{3}{*}{ Comparison } \\
\hline & & & & & & & & \\
\hline & & $\mathbf{M}$ & SD & $M$ & SD & $\mathbf{M}$ & SD & \\
\hline \multirow{3}{*}{$\begin{array}{l}\text { Technology } \\
\text { adoption }\end{array}$} & Intention to use & NA & NA & 4.54 & 1.25 & 5.23 & 1.14 & $(3)>(2)$ \\
\hline & Perceived usefulness & NA & NA & 4.62 & 1.33 & 5.28 & 1.20 & $(3)>(2)$ \\
\hline & Perceived ease of use & NA & $\mathrm{NA}$ & 3.42 & 1.17 & 4.39 & 1.29 & $(3)>(2)$ \\
\hline \multirow{3}{*}{$\begin{array}{l}\text { Security } \\
\text { beliefs }\end{array}$} & Privacy concerns* & 3.14 & 1.09 & 4.35 & 1.35 & 4.99 & 1.23 & $(3)>(2)>(1)$ \\
\hline & Trust & 5.62 & 1.12 & 4.30 & 1.41 & 3.89 & 1.01 & $(1)>(2)>(3)$ \\
\hline & Risk $^{*}$ & 4.10 & 1.28 & 5.06 & 1.24 & 5.92 & 0.88 & $(3)>(2)>(1)$ \\
\hline \multirow{7}{*}{ Shopping } & Convenience & 3.75 & 1.35 & 3.93 & 1.19 & 5.37 & 1.05 & $(3)>(2)=(1)$ \\
\hline & Word-of-mouth & 4.41 & 1.56 & 4.14 & 1.25 & 5.30 & 1.28 & $(3)>(2)=(1)$ \\
\hline & Customer service quality & 4.04 & 1.50 & 4.48 & 1.31 & 5.24 & 1.33 & $(3)>(2)>(1)$ \\
\hline & Attitude toward a retailer & 4.41 & 1.39 & 4.56 & 1.27 & 5.40 & 1.27 & $(3)>(2)=(1)$ \\
\hline & \multirow[b]{3}{*}{ EXPERIMENT 2} & \multicolumn{2}{|c|}{ (1) Unassisted } & \multicolumn{2}{|c|}{$\begin{array}{l}\text { (2) Barcode } \\
\text { scanner }\end{array}$} & \multicolumn{2}{|c|}{$\begin{array}{l}\text { (3) RFID } \\
\text { reader }\end{array}$} & \\
\hline & & \multicolumn{2}{|c|}{$\mathrm{N}=31$} & \multicolumn{2}{|c|}{$\mathrm{N}=96$} & \multicolumn{2}{|c|}{$\mathrm{N}=94$} & \\
\hline & & $\mathbf{M}$ & SD & $M$ & SD & $\mathbf{M}$ & SD & Comparison \\
\hline \multirow{3}{*}{$\begin{array}{l}\text { Technology } \\
\text { adoption }\end{array}$} & Intention to use & NA & NA & 4.90 & 1.28 & 5.63 & 1.19 & $(3)>(2)$ \\
\hline & Perceived usefulness & NA & NA & 4.74 & 1.29 & 5.27 & 1.20 & $(3)>(2)$ \\
\hline & Perceived ease of use & $\mathrm{NA}$ & NA & 3.28 & 1.29 & 4.63 & 1.26 & $(3)>(2)$ \\
\hline \multirow{3}{*}{$\begin{array}{l}\text { Security } \\
\text { beliefs }\end{array}$} & Privacy concerns ${ }^{*}$ & 3.19 & 1.13 & 4.35 & 1.28 & 5.15 & 1.21 & $(3)>(2)>(1)$ \\
\hline & Trust & 5.66 & 1.14 & 4.34 & 1.33 & 3.81 & 1.13 & $(1)>(2)>(3)$ \\
\hline & Risk* $^{*}$ & 4.21 & 1.25 & 5.00 & 1.23 & 5.94 & 0.98 & $(3)>(2)>(1)$ \\
\hline \multirow{4}{*}{ Shopping } & Convenience & 3.71 & 1.30 & 4.40 & 1.19 & 5.54 & 1.07 & $(3)>(2)>(1)$ \\
\hline & Word-of-mouth & 4.37 & 1.46 & 4.46 & 1.22 & 5.48 & 1.35 & $(3)>(2)=(1)$ \\
\hline & Customer service quality & 4.03 & 1.40 & 4.68 & 1.23 & 5.53 & 1.26 & $(3)>(2)>(1)$ \\
\hline & Attitude toward a retailer & 4.29 & 1.34 & 4.69 & 1.22 & 5.55 & 1.25 & $(3)>(2)>(1)$ \\
\hline
\end{tabular}

${ }^{*}$ For this scale, a higher value indicates a more negative view. As noted earlier, Appendix B lists the items used to measure the construct and identifies all items that are reverse coded.

RFID reader is predicted to have a more positive effect on the outcomes than is the barcode scanner. Given that we grouped intention to use, perceived usefulness, and perceived ease of use under "technology adoption outcomes," we formulate a testable hypothesis related to each construct. For instance, the hypothesis for intention to use could be stated as follows: the RFID reader, compared to the barcode scanner, will have a more positive effect on intention to use. Table 4 shows the descriptive statistics for the various constructs for each of the two hardware designs and the control group for both studies. Likewise, Table 5 shows the descriptive statistics for the various constructs for each of the three content designs and the control group for both studies. In order to analyze the data to study the impacts of technology design and content design, we used ANOVA without assuming equal variances (Games-Howell) and a Tukey HSD test to compare the means across groups. The results of these comparisons are shown in the last column of Tables 4 and 5. We first discuss the results pertaining to P1 through P3 (i.e., hardware design propositions) for experiments 1 and 2 (Table 4). We then discuss the results pertaining to P4 through P6 (i.e., content design propositions) for studies 1 and 2 (Table 5).

As noted above, the results related to P1 through P3 are shown in Table 4. P1 was supported in both experiments, with the RFID reader garnering the most favorable user reactions followed by the barcode scanner. P2 was supported in both experiments with unassisted shopping causing the least concern, was the most trusted, and least risky. The barcode scanner was the next best and the RFID reader caused the greatest concern. P3 was partially supported in experiment 1 in that the RFID reader engendered the most favorable shop- 


\begin{tabular}{|c|c|c|c|c|c|c|c|c|c|c|c|}
\hline \multirow[b]{3}{*}{ Outcomes } & \multirow[b]{3}{*}{ EXPERIMENT 1} & \multirow{2}{*}{\multicolumn{2}{|c|}{$\begin{array}{c}(1) \\
\text { Unassisted } \\
N=33\end{array}$}} & \multirow{2}{*}{\multicolumn{2}{|c|}{$\begin{array}{c}\text { (2) Product } \\
\text { info }\end{array}$}} & \multirow{2}{*}{\multicolumn{2}{|c|}{$\begin{array}{l}\text { (3) Product } \\
\text { review } \\
\mathrm{N}=61\end{array}$}} & \multirow{2}{*}{\multicolumn{2}{|c|}{$\begin{array}{c}\text { (4) Product } \\
\text { info and } \\
\text { review }\end{array}$}} & \multirow[b]{3}{*}{ Comparison } & \\
\hline & & & & & & & & & & & \\
\hline & & $M$ & SD & $M$ & SD & $M$ & SD & $M$ & SD & & \\
\hline \multirow{3}{*}{$\begin{array}{l}\text { Technology } \\
\text { adoption }\end{array}$} & Intention to use & NA & NA & 4.84 & 1.25 & 4.91 & 1.27 & 4.93 & 1.22 & $(2)=(3)=(4)$ & \\
\hline & $\begin{array}{l}\text { Perceived } \\
\text { usefulness }\end{array}$ & NA & NA & 4.96 & 1.28 & 4.92 & 1.31 & 4.97 & 1.34 & $(2)=(3)=(4)$ & \\
\hline & $\begin{array}{l}\text { Perceived ease of } \\
\text { use }\end{array}$ & NA & NA & 4.09 & 1.30 & 3.92 & 1.33 & 3.73 & 1.33 & $(2)>(3)=(4)$ & \\
\hline \multirow{3}{*}{$\begin{array}{l}\text { Security } \\
\text { beliefs }\end{array}$} & Privacy concerns* & 3.14 & 1.09 & 4.65 & 1.28 & 4.67 & 1.38 & 4.71 & 1.35 & $(2)=(3)=(4)>(1)$ & \\
\hline & Trust & 5.62 & 1.12 & 4.15 & 1.23 & 3.99 & 1.26 & 4.13 & 1.23 & $(1)>(2)=(3)=(4)$ & \\
\hline & Risk* $^{*}$ & 4.10 & 1.28 & 5.45 & 1.12 & 5.52 & 1.17 & 5.54 & 1.17 & $(2)=(3)=(4)>(1)$ & \\
\hline \multirow{7}{*}{ Shopping } & Convenience & 3.75 & 1.35 & 4.81 & 1.34 & 4.60 & 1.36 & 4.58 & 1.30 & $(2)>(3)=(4)>(1)$ & \\
\hline & Word-of-mouth & 4.41 & 1.56 & 4.65 & 1.27 & 4.75 & 1.47 & 4.79 & 1.45 & $(2)=(3)=(4)>(1)$ & \\
\hline & $\begin{array}{l}\text { Customer service } \\
\text { quality }\end{array}$ & 4.04 & 1.50 & 4.83 & 1.27 & 4.92 & 1.45 & 4.85 & 1.41 & $(2)=(3)=(4)>(1)$ & \\
\hline & $\begin{array}{l}\text { Attitude toward a } \\
\text { retailer }\end{array}$ & 4.41 & 1.39 & 4.90 & 1.33 & 5.05 & 1.42 & 5.02 & 1.28 & $(2)=(3)=(4)>(1)$ & \\
\hline & & \multicolumn{2}{|c|}{$\begin{array}{c}\text { (1) } \\
\text { Unassisted }\end{array}$} & \multicolumn{2}{|c|}{$\begin{array}{l}\text { (2) Product } \\
\text { info }\end{array}$} & \multicolumn{2}{|c|}{$\begin{array}{l}\text { (3) Product } \\
\text { review }\end{array}$} & \multicolumn{2}{|c|}{$\begin{array}{l}\text { (4) Product } \\
\text { info and } \\
\text { review }\end{array}$} & & \multirow{3}{*}{$\begin{array}{c}\text { Experiment } 1 \text { vs. } \\
\text { experiment } 2 \\
\text { (significance of } \\
\text { task interaction) }\end{array}$} \\
\hline & & \multicolumn{2}{|c|}{$N=31$} & \multicolumn{2}{|c|}{$N=65$} & \multicolumn{2}{|c|}{$N=61$} & \multicolumn{2}{|c|}{$N=64$} & & \\
\hline & EXPERIMENT 2 & M & SD & $\mathbf{M}$ & SD & M & SD & M & SD & Comparison & \\
\hline \multirow{3}{*}{$\begin{array}{l}\text { Technology } \\
\text { adoption }\end{array}$} & Intention to use & 4.19 & 1.25 & 4.88 & 1.27 & 5.37 & 1.22 & 5.55 & 1.30 & $(3)=(4)>(2)$ & Significant \\
\hline & $\begin{array}{l}\text { Perceived } \\
\text { usefulness }\end{array}$ & NA & NA & 4.91 & 1.32 & 5.13 & 1.26 & 4.99 & 1.27 & $(2)=(3)=(4)$ & Non-significant \\
\hline & $\begin{array}{l}\text { Perceived ease of } \\
\text { use }\end{array}$ & NA & NA & 3.89 & 1.39 & 3.97 & 1.46 & 3.98 & 1.37 & $(2)=(3)=(4)$ & Non-significant \\
\hline \multirow{3}{*}{$\begin{array}{l}\text { Security } \\
\text { beliefs }\end{array}$} & Privacy concerns* & 3.19 & 1.13 & 4.68 & 1.29 & 4.68 & 1.28 & 4.88 & 1.37 & $(4)>(3)=(2)>(1)$ & Non-significant \\
\hline & Trust & 5.66 & 1.14 & 4.15 & 1.30 & 3.96 & 1.28 & 4.12 & 1.25 & $(1)>(2)=(3)=(4)$ & Non-significant \\
\hline & Risk* $^{*}$ & 4.21 & 1.25 & 5.41 & 1.18 & 5.47 & 1.24 & 5.53 & 1.23 & $(2)=(3)=(4)>(1)$ & Non-significant \\
\hline \multirow{4}{*}{ Shopping } & Convenience & 3.71 & 1.30 & 4.61 & 1.22 & 5.02 & 1.31 & 5.27 & 1.20 & $(4)>(3)>(2)>(1)$ & Significant \\
\hline & Word-of-mouth & 4.37 & 1.46 & 4.57 & 1.39 & 5.04 & 1.39 & 5.30 & 1.31 & $(4)>(3)>(2)>(1)$ & Significant \\
\hline & $\begin{array}{l}\text { Customer service } \\
\text { quality }\end{array}$ & 4.03 & 1.40 & 4.77 & 1.17 & 5.19 & 1.41 & 5.34 & 1.32 & $(4)=(3)>(2)>(1)$ & Significant \\
\hline & $\begin{array}{l}\text { Attitude toward a } \\
\text { retailer }\end{array}$ & 4.29 & 1.34 & 4.76 & 1.20 & 5.20 & 1.36 & 5.40 & 1.30 & $(4)=(3)>(2)>(1)$ & Significant \\
\hline
\end{tabular}

*For this scale, a higher value indicates a more negative view. As noted earlier, Appendix B lists the items used to measure the construct and identifies all items that are reverse coded.

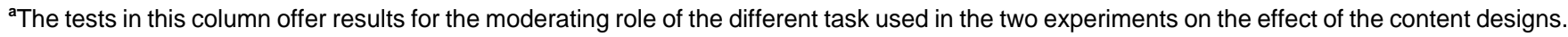
As can be seen, the nature of the task appears more important for the effect of the content design for the shopping outcomes and intention to use the artifact.

ping outcomes, but the barcode scanner was not superior to unassisted shopping in three of the four outcomes (except for customer service quality). Interestingly, in experiment 2, P3 was mostly supported as the barcode scanner was not superior in only one of the four outcomes (word-of-mouth).
As noted above, the results pertaining to P4 through P6 are shown in Table 5. First, the results for P4 were mixed; P4 was not supported in experiment 1 and partially supported in experiment 2. Product information only, product review only, and the combination were generally similar in terms of tech- 
nology adoption outcomes, with the one exception being that product information was easier to use than the other two content design conditions in experiment 1 . In experiment 2 , all content design conditions were equivalent, with the exception of intention to use, which was the lowest for the product information condition. Second, P5 was not supported in both experiments 1 and 2. In both experiments, security concerns were higher in all content design conditions in comparison to unassisted shopping, for which security concerns were lowest. Third, P6 was partially supported. In experiment 1, P6 was partially supported with the most favorable outcomes found for the combination content design condition on three of the four shopping outcomes and unassisted shopping viewed least favorably. In experiment 2, P6 was mostly supported. The combination content design condition generally emerged as the preferred option, but it was matched by the product review only condition in two of the four shopping outcomes. In the case of the other two shopping outcomes, the combination content design condition was viewed most favorably, product review was next most favorable, followed by product information, and unassisted shopping was viewed least favorably.

As a post hoc analysis, we further broke down the data into the seven treatment conditions by considering the interaction between the hardware design and content design. Such a finer-grained analysis was important for a few different reasons. First, if any specific combination is dominant as a preference among shoppers, we would not be able to detect this outcome from the prior analyses. Second, if effects were being obscured by highly non-preferred options, it may lead to misleading results. Finally, if there are consistent results across different content designs for any given hardware design or vice versa, it would have significant implications for firm strategies. These results are shown in Tables 6 and 7, with the latter table showing the ranking based on an ANOVA with a Tukey HSD for pairwise comparisons. Specifically, Table 7 shows the ranking such that those cells that were not significantly different are shown in a single line-for instance, in experiment 1 , for intention to use, cells 5, 6, and 7 are equivalent to each other followed by cells 2,3 , and 4 , which are equivalent to each other. In general, in experiment 1 , regardless of the type of content served, the RFID reader conditions were rated highest on technology adoption outcomes and shopping outcomes, and the barcode scanner was next best. In contrast, in experiment 1 , any content served appeared to produce better results in the RFID scenarios (i.e., product information engendered more favorable reactions with the RFID reader than with the barcode scanner). Interestingly, the security-related beliefs were also less favorable for the same type of content when using RFID. This pattern suggests that hardware design may have a stronger effect on outcomes when compared to the effect of content design. In experiment 2, one key difference emerges. This relates to the strong positive technology adoption and shopping outcomes related to RFID with the combination of product information and reviews followed by the RFID with product reviews. This suggests that the interaction of hardware design and content design is more pronounced for shopping outcomes in goal-directed shopping where the objective of the shopper is to choose a specific product option.

\section{Discussion}

Drawing on the growing business interest in leveraging mobile devices with auto-ID technology to aid in-store shopping, we used a design science approach to design-andbuild, theorize about, and compare six different shopping assistance artifacts on three sets of outcomes: technology adoption outcomes, security beliefs toward shopping, and shopping outcomes. We found that a RFID-based hardware design was viewed most favorably in terms of technology adoption outcomes and shopping outcomes but least favorably in terms of security. We also found support for the propositions that content design conditions (i.e., product information, product reviews, and both) engendered favorable reactions. In a post hoc analysis, we found a two-way interaction of hardware and content designs such that content fueled by RFID was most favorably received in terms of technology adoption and shopping outcomes, whereas most negatively viewed in terms of security. Finally, RFID combined with both product information and reviews was most positively received in the context of goal-directed shopping.

\section{Theoretical Implications}

This research has several important implications for theory. First, to the best of our knowledge, our research is among the first that investigated customers' reactions toward the use of RFID readers and barcode scanners in a retail environment. Our studies showed that the mobile RFID reader was perceived most favorably when assessing technology adoption outcomes, although the RFID hardware condition yielded the highest security concerns from a customer's perspective. This is intriguing because IS resistance theory proposes that technological inhibitors negatively influence individuals' technology adoption behavior above and beyond technology enablers (see Cenfetelli and Schwarz 2011). However, much prior work on mobile technologies has found that trust levels, privacy, and risk concerns are inhibitors of customers' use of a mobile device (Lu et al. 2005) and RFID-based technologies (Lehtonen et al. 2007). One reasonable explanation for our 


\begin{tabular}{|c|c|c|c|c|c|c|c|c|c|c|c|c|c|c|c|}
\hline \multirow[b]{3}{*}{ Outcomes } & \multirow[b]{3}{*}{ EXPERIMENT 1} & \multirow{2}{*}{\multicolumn{2}{|c|}{$\begin{array}{c}(1) \\
\text { Unassisted } \\
N=33\end{array}$}} & \multirow{2}{*}{\multicolumn{2}{|c|}{ 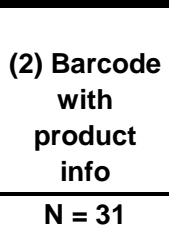 }} & \multirow{2}{*}{\multicolumn{2}{|c|}{$\begin{array}{c}\text { (3) Barcode } \\
\text { with } \\
\text { product } \\
\text { review }\end{array}$}} & \multirow{2}{*}{\multicolumn{2}{|c|}{$\begin{array}{l}\text { (4) Barcode } \\
\text { with } \\
\text { product } \\
\text { info and } \\
\text { review } \\
\mathrm{N}=34\end{array}$}} & \multirow{2}{*}{\multicolumn{2}{|c|}{$\begin{array}{c}\text { (5) RFID } \\
\text { with } \\
\text { product } \\
\text { info }\end{array}$}} & \multirow{2}{*}{\multicolumn{2}{|c|}{$\begin{array}{c}\text { (6) RFID } \\
\text { with } \\
\text { product } \\
\text { review }\end{array}$}} & \multirow{2}{*}{\multicolumn{2}{|c|}{$\begin{array}{l}\begin{array}{c}\text { (7) RFID } \\
\text { with } \\
\text { product info } \\
\text { and review }\end{array} \\
\mathrm{N}=33\end{array}$}} \\
\hline & & & & & & & & & & & & & & & \\
\hline & & $M$ & SD & $M$ & SD & $M$ & SD & $\mathbf{M}$ & SD & $M$ & SD & $M$ & SD & $M$ & SD \\
\hline \multirow{3}{*}{$\begin{array}{l}\text { Technology } \\
\text { adoption }\end{array}$} & Intention to use & 4.10 & 1.23 & 4.51 & 1.20 & 4.52 & 1.28 & 4.58 & 1.29 & 5.14 & 1.23 & 5.28 & 1.17 & 5.29 & 1.05 \\
\hline & $\begin{array}{l}\text { Perceived } \\
\text { usefulness }\end{array}$ & NA & NA & 4.58 & 1.31 & 4.67 & 1.34 & 4.60 & 1.39 & 5.30 & 1.17 & 5.17 & 1.25 & 5.35 & 1.20 \\
\hline & $\begin{array}{l}\text { Perceived ease of } \\
\text { use }\end{array}$ & NA & NA & 3.57 & 1.23 & 3.50 & 1.28 & 3.20 & 1.00 & 4.55 & 1.20 & 4.32 & 1.28 & 4.28 & 1.41 \\
\hline \multirow{3}{*}{$\begin{array}{l}\text { Security } \\
\text { beliefs }\end{array}$} & Privacy concerns* & 3.14 & 1.09 & 4.28 & 1.29 & 4.34 & 1.35 & 4.41 & 1.45 & 4.98 & 1.20 & 4.99 & 1.35 & 5.01 & 1.18 \\
\hline & Trust & 5.62 & 1.12 & 4.20 & 1.45 & 4.23 & 1.43 & 4.45 & 1.38 & 4.10 & 1.01 & 3.75 & 1.05 & 3.80 & 0.98 \\
\hline & Risk* & 4.10 & 1.28 & 5.05 & 1.23 & 5.07 & 1.27 & 5.07 & 1.25 & 5.80 & 0.89 & 5.95 & 0.88 & 6.02 & 0.87 \\
\hline \multirow{7}{*}{ Shopping } & Convenience & 3.75 & 1.35 & 4.01 & 1.12 & 4.00 & 1.42 & 3.80 & 1.04 & 5.51 & 1.11 & 5.19 & 1.01 & 5.38 & 1.03 \\
\hline & Word-of-mouth & 4.41 & 1.56 & 4.08 & 1.28 & 4.13 & 1.29 & 4.19 & 1.23 & 5.15 & 1.05 & 5.35 & 1.40 & 5.40 & 1.41 \\
\hline & $\begin{array}{l}\text { Customer service } \\
\text { quality }\end{array}$ & 4.04 & 1.50 & 4.41 & 1.20 & 4.48 & 1.38 & 4.53 & 1.39 & 5.20 & 1.23 & 5.35 & 1.41 & 5.18 & 1.38 \\
\hline & $\begin{array}{l}\text { Attitude toward a } \\
\text { retailer }\end{array}$ & 4.41 & 1.39 & 4.45 & 1.31 & 4.57 & 1.39 & 4.65 & 1.16 & 5.29 & 1.23 & 5.51 & 1.31 & 5.41 & 1.30 \\
\hline & \multirow[b]{3}{*}{ EXPERIMENT 2} & \multicolumn{2}{|c|}{$\begin{array}{c}\text { (1) } \\
\text { Unassisted }\end{array}$} & \multicolumn{2}{|c|}{$\begin{array}{l}\text { (2) Barcode } \\
\text { with } \\
\text { product } \\
\text { info }\end{array}$} & \multicolumn{2}{|c|}{$\begin{array}{l}\text { (3) Barcode } \\
\text { with } \\
\text { product } \\
\text { review }\end{array}$} & \multicolumn{2}{|c|}{$\begin{array}{l}\text { (4) Barcode } \\
\text { with } \\
\text { product } \\
\text { info and } \\
\text { review }\end{array}$} & \multicolumn{2}{|c|}{$\begin{array}{l}\text { (5) RFID } \\
\text { with } \\
\text { product } \\
\text { info }\end{array}$} & \multicolumn{2}{|c|}{$\begin{array}{l}\text { (6) RFID } \\
\text { with } \\
\text { product } \\
\text { review }\end{array}$} & \multicolumn{2}{|c|}{$\begin{array}{l}\text { (7) RFID } \\
\text { with } \\
\text { product } \\
\text { info and } \\
\text { review }\end{array}$} \\
\hline & & \multicolumn{2}{|c|}{$\mathrm{N}=31$} & \multicolumn{2}{|c|}{$\mathrm{N}=34$} & \multicolumn{2}{|c|}{$N=30$} & \multicolumn{2}{|c|}{$N=32$} & \multicolumn{2}{|c|}{$\mathrm{N}=\mathbf{3 1}$} & \multicolumn{2}{|c|}{$\mathrm{N}=\mathbf{3 1}$} & \multicolumn{2}{|c|}{$\mathrm{N}=32$} \\
\hline & & $M$ & SD & $M$ & SD & $M$ & SD & $M$ & SD & $M$ & SD & $M$ & SD & $M$ & SD \\
\hline \multirow{3}{*}{$\begin{array}{l}\text { Technology } \\
\text { adoption }\end{array}$} & Intention to use & 4.19 & 1.25 & 4.58 & 1.22 & 5.13 & 1.31 & 5.01 & 1.31 & 5.20 & 1.26 & 5.61 & 1.10 & 6.08 & 1.07 \\
\hline & $\begin{array}{l}\text { Perceived } \\
\text { usefulness }\end{array}$ & NA & NA & 4.55 & 1.37 & 5.08 & 1.28 & 4.63 & 1.25 & 5.30 & 1.17 & 5.17 & 1.25 & 5.35 & 1.20 \\
\hline & $\begin{array}{l}\text { Perceived ease of } \\
\text { use }\end{array}$ & NA & NA & 3.23 & 1.21 & 3.29 & 1.31 & 3.31 & 1.09 & 4.61 & 1.22 & 4.63 & 1.29 & 4.65 & 1.31 \\
\hline & Privacy concerns* & 3.19 & 1.13 & 4.31 & 1.26 & 4.30 & 1.26 & 4.44 & 1.40 & 5.08 & 1.22 & 5.05 & 1.21 & 5.31 & 1.21 \\
\hline $\begin{array}{l}\text { security } \\
\text { beliefs }\end{array}$ & Trust & 5.66 & 1.14 & 4.28 & 1.40 & 4.27 & 1.34 & 4.47 & 1.34 & 4.01 & 1.18 & 3.66 & 1.17 & 3.77 & 1.05 \\
\hline & Risk* $^{*}$ & 4.21 & 1.25 & 4.99 & 1.20 & 5.01 & 1.29 & 5.01 & 1.29 & 5.88 & 0.98 & 5.91 & 1.03 & 6.04 & 0.94 \\
\hline & Convenience & 3.71 & 1.30 & 4.07 & 1.07 & 4.51 & 1.40 & 4.66 & 1.06 & 5.20 & 1.10 & 5.52 & 1.01 & 5.88 & 1.01 \\
\hline & Word-of-mouth & 4.37 & 1.46 & 4.05 & 1.29 & 4.57 & 1.23 & 4.79 & 1.07 & 5.13 & 1.28 & 5.49 & 1.40 & 5.80 & 1.34 \\
\hline Shopping & $\begin{array}{l}\text { Customer service } \\
\text { quality }\end{array}$ & 4.03 & 1.40 & 4.37 & 1.13 & 4.80 & 1.31 & 4.89 & 1.24 & 5.21 & 1.07 & 5.57 & 1.41 & 5.79 & 1.25 \\
\hline & $\begin{array}{l}\text { Attitude toward a } \\
\text { retailer }\end{array}$ & 4.29 & 1.34 & 4.39 & 1.22 & 4.79 & 1.32 & 4.91 & 1.13 & 5.17 & 1.06 & 5.59 & 1.31 & 5.89 & 1.28 \\
\hline
\end{tabular}

*For this scale, a higher value indicates a more negative view. As noted earlier, Appendix B lists the items used to measure the construct and identifies all items that are reverse coded. 


\begin{tabular}{|c|c|c|c|}
\hline Outcomes & & Experiment 1 & Experiment 2 \\
\hline \multirow{3}{*}{$\begin{array}{l}\text { Technology } \\
\text { adoption }\end{array}$} & Intention to use & $\begin{array}{l}5,6,7 \\
2,3,4\end{array}$ & $\begin{array}{l}7 \\
6 \\
3,4,5 \\
2\end{array}$ \\
\hline & Perceived usefulness & $\begin{array}{l}5,6,7 \\
2,3,4\end{array}$ & $\begin{array}{l}5,6,7 \\
3 \\
2,4\end{array}$ \\
\hline & Perceived ease of use & $\begin{array}{l}5,6,7 \\
2,3 \\
4\end{array}$ & $\begin{array}{l}5,6,7 \\
2,3,4\end{array}$ \\
\hline \multirow{3}{*}{$\begin{array}{l}\text { Security } \\
\text { beliefs }\end{array}$} & Privacy concerns ${ }^{\star}$ & $\begin{array}{l}5,6,7 \\
2,3,4 \\
1\end{array}$ & $\begin{array}{l}7 \\
5,6 \\
2,3,4 \\
1\end{array}$ \\
\hline & Trust & $\begin{array}{l}1 \\
4 \\
2,3,5 \\
6,7\end{array}$ & $\begin{array}{l}1 \\
2,3,4 \\
5 \\
6,7\end{array}$ \\
\hline & Risk $^{*}$ & $\begin{array}{l}5,6,7 \\
2,3,4 \\
1\end{array}$ & $\begin{array}{l}5,6,7 \\
2,3,4 \\
1\end{array}$ \\
\hline \multirow{4}{*}{ Shopping } & Convenience & $\begin{array}{l}5,6,7 \\
2,3 \\
1,4\end{array}$ & $\begin{array}{l}7 \\
6 \\
5 \\
3,4 \\
2 \\
1 \\
\end{array}$ \\
\hline & Word-of-mouth & $\begin{array}{l}6,7 \\
5 \\
1 \\
2,3,4\end{array}$ & $\begin{array}{l}7 \\
6 \\
5 \\
1,3,4 \\
2\end{array}$ \\
\hline & Customer service quality & $\begin{array}{l}5,6,7 \\
2,3,4 \\
1\end{array}$ & $\begin{array}{l}6,7 \\
5 \\
3,4 \\
2 \\
1 \\
\end{array}$ \\
\hline & Attitude toward a retailer & $\begin{array}{l}5,6,7 \\
1,2,3,4\end{array}$ & $\begin{array}{l}7 \\
5,6 \\
3,4 \\
1,2\end{array}$ \\
\hline
\end{tabular}

Cell numbers in columns 3 and 4 are: (1) Unassisted; (2) Barcode with product info; (3) Barcode with product review; (4) Barcode with product info and review; (5) RFID with product info; and (6) RFID with product review; (7) RFID with product info and review. For the unassisted control condition (cell 1), participants were not asked questions for intention to use, perceived usefulness, or perceived ease of use.

*For this scale, a higher value indicates a more negative view. As noted earlier, Appendix B lists the items used to measure the construct and identifies all items that are reverse coded. 
findings might be that the convenience associated with the RFID reader outweighed participants' security concerns in this particular context. Future studies could build upon these findings and provide a more nuanced understanding of the relationship between security concerns and technology adoption outcomes related to mobile RFID readers.

Second, our study extends research on auto-ID technology adoption to the individual level. Prior research has primarily focused on leveraging auto-ID technologies for managing inventory and providing technology-mediated inventory visibility at the organizational level (e.g., Hardgrave et al. 2013). However, we were unable to identify any empirical research that has examined using auto-ID technologies to provide product visibility to customers. Although the applicability check conducted with practitioners found that retailers are currently exploring auto-ID-based mobile applications to enhance overall shopping experience, prior literature on privacy, trust, and risk in the context of individual level autoID adoption has not holistically evaluated customers' actual experiences with RFID. We extend prior work, which has primarily used cross-sectional surveys in nonuse contexts, by using different configurations of shopping assistance artifacts providing product visibility to shoppers in a retail environment, theorizing and testing how the artifacts compared in terms of technology adoption outcomes, security beliefs, and shopping outcomes, and thus shedding light on the pros and cons of these emerging technologies.

Third, e-commerce research has become one of the most established streams in the IS literature and recommendation agents are well understood (see Gefen et al. 2003; Senecal and Nantel 2004). Yet, little is known about how customer product reviews can be integrated into mobile applications, despite a growing interest from practitioners (e.g., RIS Research 2012b). Following a rigorous design science research approach, we built shopping assistance artifacts that offered product reviews and product information in a smartphone application. Based on prior e-commerce research (Gefen et al. 2003), we expected that product reviews and product information would positively influence customers' security perceptions. Our findings suggest that customers in all content design conditions were more concerned about shopping security than were unassisted shoppers. This suggests that, although beneficial in e-commerce environments, product reviews and product information in a mobile environment may not contribute to customers' trust perceptions to the same degree as in an e-commerce environment. Thus, our study helps advance trust research in the context of mobile applications.

Fourth, our design science approach contributes to HCI and mobile application usability research because we illustrate how to holistically evaluate the impact of a newly designed technology artifact on individuals and organizations in laboratory research environments. Traditionally, HCI researchers have designed and tested technology artifacts in laboratory research environments (e.g., Hornbaek and Frokjaer 2008) using think aloud protocols or cognitive walkthrough inspections, error rates, and by gauging the time to complete a predefined task (e.g., Kaikkonen et al. 2005). Our design science approach complements such studies by systematically creating an artifact (e.g., by conducting the applicability checks with practitioners) and evaluating its impacts on broad customer outcomes.

Finally, this research illustrates the use of design science as a possible methodology for conducting marketing research. We identified all eight components of the information systems design science principles outlined by Gregor and Jones (2007) and showed how they can be applied to the mobile shopping artifact context. Our work could thus encourage marketing researchers to embrace the design science approach to address technology-related marketing concepts (e.g., viral marketing, mobile marketing, digital marketing). Researchers have attempted to explain why customers accept or resist marketing approaches on their smartphones (e.g., Jayawardhena et al. 2009) by using cross-sectional surveys or qualitative research methods (e.g., grounded theory). As our findings have shown, asking individuals to "touch, feel, and experience" technologies can yield rich insights about customer reactions. Thus, by embracing the design science approach, marketing researchers can enrich both marketing theory and practice as it relates to customer use of technologies in different contexts.

\section{Practical Implications}

Mobile application designers developing mobile solutions for retail environments can benefit from our work for two major reasons. First, we demonstrated how innovative hardware (RFID) technology in combination with a mobile shopping application could be leveraged in retail settings. The RFIDbased mobile shopping artifact was viewed favorably in terms of technology adoption outcomes compared to the barcodebased mobile shopping artifact. Mobile solution developers employ RFID in combination with mobile applications and test them using evaluation techniques such as the ones used in this work. Potential mobile solutions that combine hardware and software designs could include NFC hardware with mobile payments or GPS technologies with mobile marketing applications.

From a retailer perspective, our findings indicate a number of favorable effects associated with the use of the technologies (relative to the control condition) and these outcomes are 
particularly impressive for RFID. Specifically, our results show that shoppers perceive greater convenience and service quality when using RFID as an aid in their shopping. Perhaps more importantly, these benefits appear to extend beyond the immediate in-store shopper experience, with shoppers reporting a more favorable attitude toward the retailer and a higher likelihood to engage in word-of-mouth about the retail store. Although there also are some positive effects of the use of the barcode scanner, the effects on the shopping outcomes clearly favor the RFID reader. Also, results became stronger in the RFID condition as the shopping task became more goal-oriented and concrete (Krantz and Kunreuther 2007), and specific options within a product category were examined and evaluated (i.e., experiment 2). As shown in Table 7, when more comprehensive information within a product category is available (both reviews and product information) for the goaldirected shopping task, the RFID-based content has more favorable effects, relative to both the barcode and the control conditions, on three of the four shopping outcomes. It is important to note that these favorable effects on the shopping outcomes are occurring despite the fact that respondents viewed the hardware designs as least secure compared to barcode technology and traditional unassisted shopping. This pattern of findings suggest that, although there may be some concerns related to use of the technology, the shopping outcome benefits (e.g., convenience, service quality) may counter such concerns in this specific context and the favorable effects may extend to more general outcomes (e.g., attitude toward the retailer).

\section{Study Limitations and Future Research}

Our research design has some limitations and these can serve as opportunities for future research. We organize these into three broad areas: technological aspects, methodological and contextual extensions, and alternative outcome variables.

\section{Technological Aspects}

Handheld RFID readers can set the range of the read area and for the purposes of a shopping assistance artifact that focuses on obtaining product information, the appropriate range is a few inches. We did not measure the percentage or quantity of unintentional reads and future research could study that. There are also scanning artifacts other than the barcodes, which we used here, that require direct line-of-sight (e.g., QR codes, 3D barcodes) These artifacts may have performed differently than barcodes and, therefore, should be studied in the future. It is also important to note our mobile applications were not dependent on Internet access because to maintain experimental control, we preinstalled information and product reviews before asking the participants to complete the experimental tasks. Future research should investigate if Internetbased mobile applications (e.g., mobile sites that can be accessed through mobile Internet browsers) are viewed as more secure and trustworthy compared to the preinstalled mobile shopping assistance applications used in our work in order to maintain experimental control. It would also be interesting to evaluate potential effects that independent review sites (for an example, see DP Review 2013) may have on customers' perceptions related to mobile shopping artifacts.

\section{Methodological and Contextual Extensions}

We designed our experiments to understand customers' reactions toward auto-ID enabled mobile shopping assistance artifacts in general retail store environments. Our work should be replicated in other contexts (e.g., mobile healthcare, specific sectors such as the apparel industry) and the applicability of our mobile shopping artifact in these environments should be tested. Likewise, it will be interesting to extend our study by integrating additional mobile application features that are commonly leveraged by social media applications (e.g., short video clips, live chat). It would also be helpful to study differences in effects for infrequently purchased high involvement products (i.e., those in which shoppers are particularly interested and perceive to be important) versus frequently purchased low involvement products ( $\mathrm{Gu}$ et al. 2012). Future studies could also investigate if customer processing behavior is influenced by product type, including those typically classified as categories more likely to be processed in a heuristic or systematic manner.

Another opportunity for future research is to account for the interrelationships among constructs and the development of a nomological networks. For instance, trust and risk are interrelated with information privacy and recent work suggests that experimental studies are well suited to discover mediation effects among variables (Bullock et al. 2010). However, future studies could investigate possible interrelationships and examine the nomological network surrounding the use of shopping assistance artifacts, such as mobile application usability (Hoehle and Venkatesh 2015). For instance, one of the possible future directions could be examining how the effects of hardware and content design carry to the various outcomes. It is believed that such design characteristics will influence various perceptions (see Venkatesh and Bala 2008), for example, usability (Hoehle and Venkatesh 2015) or technology-related beliefs (e.g., Venkatesh et al. 2012). Understanding how the impacts of technology design carry through to outcomes is important both from a design science and behavioral theory perspective. Further, understanding the role of potential moderators in such an expanded nomological 
network will help develop a richer and more holistic understanding of such emerging technologies, their impacts, and in promoting their success for firms. Specifically, different types of moderating variables may play a role in an expanded nomological network-for example, demographic characteristics such as gender (Venkatesh et al. 2012), technologyrelated variables such as computer anxiety (Venkatesh 2000), or more general traits such as the big-five- that links designs with outcomes.

We conducted two sequential experiments. Thus, the data were collected at different points in time and the participants were not randomly assigned to the two different task conditions. Due to this, we did not directly evaluate the influence of task characteristics on the outcomes of interest in our study. There is a considerable amount of research in the area of HCI that the nature of task is an important factor when assessing individuals' reactions to mobile applications. Thus, future research should investigate the interplay between various task characteristics (e.g., task complexity), the outcomes of interest, and manipulations of the mobile assistance shopping artifacts.

There are a number of opportunities for future research from a marketing perspective that would broaden the methodological context used in our studies. For example, offering coupons within the specific category to the customer in promotion efforts could influence brand choice. Research could address whether such efforts would allow retailers to aggressively market store brands with both nondiscounted price comparisons, (favorable) product ratings suggesting value, or conventional couponing. Similar promotion efforts delivered using a shopping assistance artifact could be directed to complementary products that might serve to increase the total dollar sales per customer. However, efforts that encourage the use of mobile shopping devices potentially empower customers by offering the chance to engage in price comparisons for both online retailers and nearby brick-andmortar competitors, and future research should examine the relative benefits and threats. As noted earlier, these ideas call for using the design science approach in conjunction with marketing concepts to gain a richer understanding of consumer behavior in technology-mediated shopping contexts.

We conducted our experiment in a laboratory environment including a relatively small store front offering a limited number of product options. When major retailers begin to enable mobile RFID applications in their stores, ${ }^{7}$ future

\footnotetext{
${ }^{7}$ To the best of our knowledge, the French retailer Casino is the only retailer that has an operational radio frequency scan test-store set up for customers to use an application to scan products (for details, see NFC World 2012).
}

research could replicate our work in an actual store environment in which shoppers purchase products. A test in the field could examine the ecological validity of our conclusions, albeit at the expense of the experimental control we maintained. Further, due to our experimental research design, our participants were not given a choice to consult retailerindependent, product-specific online review applications, such as digital photography review (DP Review 2013). These independent review applications specialize in product reviews and shoppers trust perceptions might differ from those observed in our work.

In order for our findings to be leveraged in practice, a key issue that should be further investigated is the concern about security that emerged in the RFID conditions. Future studies may examine specific manipulations related to shopper concerns about privacy and risk and how such manipulations affect important outcomes. Examples include manipulating the number of involuntary reads by the RFID reader (by manipulating the range of the reader) and manipulating the removability of the tags after purchase. Both of these factors may cause heightened privacy concerns.

\section{Alternative Outcome Variables}

Other potential dependent variables, such as customer loyalty and patronage, are worthy of study. For instance, by choosing shopping assistance artifacts as an innovation strategy, firms could potentially influence various phases of customer loyalty (see Xu et al. 2014). Similarly, in our experiments with the use of this artifact and the retail contexts examined, the specific items used focused on the word-of-mouth toward the retailer and not the specific product(s) considered. However, word-of-mouth for the product is certainly of future interest, particularly from the product manufacturer's perspective. It would also be interesting to study the effect of negative product reviews on shopping outcomes.

Given the overall amount of time that participants spent on the experimental task (i.e., studying the instructions, evaluating the artifact, and choosing products), we intentionally kept our survey instrument relatively short. Due to this, we measured the outcomes of interest generally at a broad level and we did not capture specific antecedent variables or higher-order factor structures that may help to explain the drivers of the outcomes of interest. Future work could address this issue to provide a more fine-grained view incorporating, for example, subdimensions of trust beliefs for getting information online, trust beliefs for purchasing products online, and trust beliefs toward the web vendor (Pavlou and Feygenson 2006). 


\section{Conclusions}

We designed and studied auto-ID enabled shopping assistance artifacts, and manipulated the hardware design and application content in two sequential experiments. This work contributes to technology adoption research by helping us gain a more complete understanding of the potential impacts of auto-ID technologies, especially RFID. Not only did we observe positive outcomes for RFID, but also we found different types of content were generally viewed favorably. However, this was not without some less favorable consequences for the RFID reader, as shoppers had some concerns from a security perspective. Given the paucity of research that has examined how emerging hardware design (e.g., barcode scanners and RFID readers) and content design (e.g., product information, product reviews) can be leveraged by retail stores to enhance shopper benefits, our work makes important contributions to the emerging body of research on auto-ID technologies and mobility.

\section{Acknowledgments}

The authors thank Dr. Eric Ngai, the senior editor, for his comments and advice on the manuscript. The authors also thank the associate editor and reviewers for their guidance. We are grateful to Jan DeGross for her excellent work in copyediting and typesetting this manuscript.

\section{References}

Adipat, B., Zhang, D., and Zhou, L. 2011. “The Effect of TreeView Based Presentation Adaptation on Mobile Web-browsing," MIS Quarterly (35:1), pp. 99-121.

Agarwal, R., and Venkatesh, V. 2002. “Assessing a Firm’s Web Presence: A Heuristic Evaluation Procedure for the Measurement of Usability,” Information Systems Research (13:2), pp. 168-186.

Ajzen, I. 1991. “The Theory of Planned Behavior,” Organizational Behavior and Human Decision Processes (50:2), pp. 179-211.

Aloysius, J., Deck, C. and Farmer, A. 2013. "Sequential Pricing of Multiple Products: Leveraging Revealed Preferences of Retail Customers Online and with Auto-ID Technologies," Information Systems Research (24:2), pp. 372-393.

Angrisani, C. 2013. "Smartphone Technology Puts Mobile Scanning Power in Customers’ Hands,” Supermarket News (available online at http://supermarketnews.com/technology/smartphonetechnology-puts-mobile-scanning-power-customers-hands).

Bansal, H. S., and Voyer, P. A. 2000. "Word-of-Mouth Processes Within a Services Purchase Decision Context," Journal of Service Research (3:2), pp. 166-177.

Bart, Y., Shankar, V., Sultan, F., and Urban, G. L. 2005. “Are the Drivers and Role of Online Trust the Same for All Web Sites and Customers? A Large-Scale Exploratory Empirical Study,” Journal of Marketing (69:4), pp. 133-152.
Beitelspacher, L. S., Hansen, J. D., Johnston, A. C., and Deitz, G. D. 2012. "Exploring Consumer Privacy Concerns and RFID Technology: The Impact of Fear Appeals on Consumer Behaviors,” Journal of Marketing Theory and Practice (20:2), pp. 147-160.

Belanger, F., and Crossler, R. E. 2011. "Privacy in the Digital Age: A Review of Information Privacy Research in Information Systems,” MIS Quarterly (35:4), pp. 1017-1041.

Berry, L. L., Seiders, K., and Grewal, D. 2002. "Understanding Service Convenience,” Journal of Marketing (66:3), pp. 1-17.

Bitner, M. J., and Hubbert, A. R. 1994. "Encounter Satisfaction Versus Overall Satisfaction Versus Quality,” in Service Quality New Directions in Theory and Practice, R. T. Rust and R. L. Oliver (eds.), New York: Sage Publications, pp. 72-84.

Bloch, P. H., Ridgway, N. M., and Sherrell, D. L. 1989. "Extending the Concept of Shopping: An Investigation of Browsing Activity," Journal of the Academy of Marketing Science (17:1), pp. 13-21.

Bloch, P. H., Sherrell, D., and Ridgway, N. M. 1986. “Consumer Search: An Extended Framework," Journal of Consumer Research (13:1), pp. 119-126.

Bose, I., Ngai, E. W. T., Teo, T. S. H., and Spiekermann, S. 2009. "Managing RFID Projects in Organizations,” European Journal of Information Systems (18:6), pp. 534-540.

Brady, M. K., Voorhees, C. M., and Brusco, M. J. 2012. "Service Sweethearting: Its Antecedents and Customer Consequences," Journal of Marketing (76:2), pp. 81-98.

Brown, L. G. 1989. "The Strategic and Tactical Implications of Convenience in Consumer Product Marketing," Journal of Consumer Marketing (6:3), pp. 13-19.

Brown, S. A., and Venkatesh, V. 2005. "Model of Adoption of Technology in Households: A Baseline Model Test and Extension Incorporating Household Life Cycle,” MIS Quarterly (29:3), pp. 399-426.

Bruner, G. C. 2009. Marketing Scales Handbook: A Compilation of Multi-Item Measures for Customer Behavior \& Advertising (Vol. 5), Carbondale, IL: GCBII Productions.

Bullock, J. G., Green, D. P., and Ha, S. E. 2010. "Yes, But What's the Mechanism? (Don't Expect an Easy Answer)," Journal of Personality and Social Psychology (98:4), pp. 550-558.

Businesswire. 2011. "Ready, Set, Scan: Stop \& Shop Launches Scan It! Mobile App” (available online at http://www. businesswire.com/news/home/20110707006493/en/Ready-SetScan-Stop-Shop-Launches-Scan).

Cazier, J. A., Jensen, A. S., and Dave, D. S. 2008. "The Impact of Consumer Perceptions of Information Privacy and Security Risks on the Adoption of Residual RFID Technologies," Communications of the Association for Information Systems (23:1), pp. 235-256.

Cenfetelli, R., and Schwarz, A. 2011. "Identifying and Testing the Inhibitors of Technology Usage Intentions,” Information Systems Research (22:4), pp. 808-823.

Chaiken, S., Liberman, A., and Eagly, A. H. 1989. "Heuristic and Systematic Processing Within and Beyond the Persuasion Context,” in Unintended Thought, J. S. Uleman and J. A. Bargh (eds.), New York: Guilford Press, pp.212-252. 
Chan, F. K., Thong, J. Y. L., Venkatesh, V., Brown, S., Hu, P., and Tam, K. Y. 2010. "Modeling Citizen Satisfaction with Mandatory Adoption of an e-Government Technology,” Journal of the Association for Information Systems (11:10), pp. 519-549.

Chan, Y., and Ngai, E. W. T. 2011. Conceptualising Electronic Word of Mouth Activity: An Input-Process-Output Perspective,” Marketing Intelligence and Planning (29:5), pp. 488- 516.

Cheung, C. M., Chan, G. W., and Limayem, M. 2005. “A Critical Review of Online Consumer Behavior: Empirical Research,” Journal of Electronic Commerce in Organizations (3:4), pp. 1-19.

Cheung, C. M., and Lee, M. K. 2012. "What Drives Consumers to Spread Electronic Word of Mouth in Online Consumer-opinion Platforms,” Decision Support Systems (53:1), pp. 218-225.

Chiu, C. M., Wang, E. T., Fang, Y. H., and Huang, H. Y. 2014. “Understanding Customers' Repeat Purchase Intentions in B2C e-Commerce: The Roles of Utilitarian Value, Hedonic Value and Perceived Risk,” Information Systems Journal (24:1), pp. 85-114.

Delen, D., Hardgrave B. C., and Sharda, R. 2007. "RFID for Better Supply-Chain Management Through Enhanced Information Visibility," Production and Operations Management (16:5), pp. 613-624.

Donthu, N., and Gilliland, D. 1996. "Observations: The Infomercial Shopper,” Journal of Advertising Research (36:2), pp. 69-76.

DP Review. 2013. Online source http://www.dpreview.com.

Duan, W., Gu, B., and Whinston, A. B. 2008. "The Dynamics of Online Word-of-mouth and Product Sales-An Empirical Investigation of the Movie Industry,” Journal of Retailing (84:2), pp. 233-242.

Elliott, M. T., and Speck, P. S. 2005. "Factors That Affect Attitude Toward a Retail Website,” Journal of Marketing Theory and Practice (13), pp. 40-51.

Forman, C., Ghose, A., and Wiesenfeld, B. 2008. "Examining the Relationship between Reviews and Sales: The Role of Reviewer Identity Disclosure in Electronic Markets,” Information Systems Research (19:3), pp. 291-313.

Gefen, D., Karahanna, E., and Straub, D. W. 2003. “Trust and TAM in Online Shopping: An Integrated Model,” MIS Quarterly (27:1), pp. 51-90.

Gregor, S., and Hevner, A. 2013. "Positioning and Presenting Design Science Research for Maximum Impact,” MIS Quarterly (37:2), pp. 337-355.

Gregor, S., and Jones, D. 2007. "The Anatomy of a Design Theory," Journal of the Association for Information Systems (8:5), pp. 312-335.

Gu, B., Park, J., and Konana, P. 2012. “The Impact of External Word-of-Mouth Sources on Retailer Sales of High-Involvement Products,” Information Systems Research (23:1), pp. 182-196.

Gunasekaran, A., and Ngai, E. W. T. 2004. "Information Systems in Supply Chain Integration and Management," European Journal of Operational Research (159:2), pp. 269-295.

Hardgrave, B. C., Aloysius, J. A., and Goyal, S. 2013. "RFIDEnabled Visibility and Retail Inventory Record Inaccuracy: Experiments in the Field," Production and Operations Management, (22:4), pp. 843-856.
Hardgrave, B. C., Goyal, S., Aloysius J. A. 2011. "Improving Inventory Management in the Retail Store: The Effectiveness of RFID Tagging across Product Categories,” Operations Management Research (4:1-2), pp. 6-13.

Hess, T. J., Fuller, M. A., and Mathew, J. 2005. “Involvement and Decision-Making Performance with a Decision Aid: The Influence of Social Multimedia, Gender, and Playfulness," Journal of Management Information Systems (22:3), pp. 15-54.

Hoehle, H., Huff, S., and Goode, S. 2012. "The Role of Continued Trust in Information Systems Continuance,” Journal of Computer Information Systems (52:4), pp. 1-9.

Hoehle, H., and Venkateh, V. 2015. "Mobile Application Usability: Conceptualization and Instrument Development,” MIS Quarterly (39:2), pp. 435-472.

Hong, S. J., and Tam, K. Y. 2006. "Understanding the Adoption of Multipurpose Information Appliances: The Case of Mobile Data Services,” Information Systems Research (17:2), pp. 162-179.

Hong, S. J., Thong, J. Y. L., and Tam, K. Y. 2006. "Understanding Continued Information Technology Usage Behavior: A Comparison of Three Models in the Context of Mobile Internet," Decision Support Systems (42:3), pp. 1819-1834.

Hong, S. J., Thong, J. Y. L., Moon, J. Y., and Tam, K. Y. 2008. "Understanding the Behavior of Mobile Data Services Customers,” Information Systems Frontiers (10:4), pp. 431-445.

Hong, W., Thong, J. Y. L., and Tam, K. Y. 2007. "How Do Web Users Respond to Non-banner-ads Animation? The Effects of Task Type and User Experience," Journal of the American Society for Information Science and Technology (58:10), pp. 1467-1482.

Hornbaek, K., and Frokjaer, E. 2008. “A Study of the Evaluator Effect in Usability Testing," Human-Computer Interaction (23:3), pp. 251-277.

Jayawardhena, C., Kuckertz, A., Karjaluoto, H., and Kautonen, T. 2009. "Antecedents to Permission Based Mobile Marketing: An Initial Examination,” European Journal of Marketing (43:3/4), pp. 473-499.

Jih, W.-J. 2007. "Effects of Consumer-Perceived Convenience on Shopping Intention in Mobile Commerce: An Empirical Study," International Journal of E-Business Research (3:4), pp. 33-48.

Jun, M., Yang, Z., and Kim, D. 2004. “Customers’ Perceptions of Online Retailing Service Quality and Their Satisfaction,” International Journal of Quality \& Reliability Management (21:8), pp. 817-840.

Kaikkonen, A., Kekäläinen, A., Cankar, M., Kallio, T., and Kankainen, A. 2005. "Usability Testing of Mobile Applications: A Comparison Between Laboratory and Field Testing," Journal of Usability Studies (1:1), pp. 4-16.

Kelley, E. J. 1958. “The Importance of Convenience in Consumer Purchasing,” Journal of Marketing (23:1), pp. 32-38.

Kim, D. J., Ferrin, D. L., and Rao, H. R. 2009. "Trust and Satisfaction, Two Stepping Stones for Successful e-Commerce Relationships: A Longitudinal Exploration," Information Systems Research (20:2), pp. 237-257.

Kim, S., and Garrison, G. 2009. "Investigating Mobile Wireless Technology Adoption: An Extension of the Technology Acceptance Model,” Information Systems Frontiers (11:3), pp. 323-333. 
Kotler, P., and Keller, K. L. 2006. Framework for Marketing Management, Upper Saddle River, NJ: Prentice-Hall.

Kowatsch, T., and Maass, W. 2010. "In-store Consumer Behavior: How Mobile Recommendation Agents Influence Usage Intentions, Product Purchases, and Store Preferences," Computers in Human Behavior (26:4), pp. 697-704.

Krantz, D. H., and Kunreuther, H. C. 2007. "Goals and Plans in Decision Making,” Judgment and Decision Making (2:3), pp. 137-168.

Lehtonen, M. O., Michahelles, F., and Fleisch, E. 2007. "Trust and Security in RFID-based Product Authentication Systems,” IEEE Systems Journal (1:2), pp. 129-144.

Li, X., and Hitt, L. M. 2010. "Price Effects in Online Product Reviews: An Analytical Model and Empirical Analysis,” MIS Quarterly (34:4), pp. 809-832.

Li, X., Hitt, L. M., and Zhang, Z. J. 2011. "Product Reviews and Competition in Markets for Repeat Purchase Products,” Journal of Management Information Systems (27:4), pp. 9-42.

Lowry, P. B., Vance, A., Moody, G., Beckman, B., and Read, A. 2008. "Explaining and Predicting the Impact of Branding Alliances and Web Site Quality on Initial Consumer Trust of e-Commerce Web Sites,” Journal of Management Information Systems (24:4), pp. 199-224.

Lu, J., Yao, J. E., and Yu, C. S. 2005. “Personal Innovativeness, Social influences and Adoption of Wireless Internet Services via Mobile Technology," The Journal of Strategic Information Systems (14:3), pp. 245-268.

Luo, X., Li, H., Zhang, J., and Shim, J. P. 2010. “Examining Multidimensional Trust and Multi-faceted Risk in Initial Acceptance of Emerging Technologies: An Empirical Study of Mobile Banking Services,” Decision Support Systems (49:2), pp. 222-234.

Maheswaran, D., Mackie, D., and Chaiken, S. 1992. "Brand Name as a Heuristic Cue: The Effects of Task Importance and Expectancy Confirmation on Consumer Judgments," Journal of Consumer Psychology (1:4), pp. 317-336.

Mallat, N. 2007. "Exploring Consumer Adoption of Mobile Payments-A Qualitative Study,” Journal of Strategic Information Systems (16:4), pp. 413-432.

McFarlane, D., and Sheffi, Y. 2003. "The Impact of Automatic Identification on Supply Chain Operations," International Journal of Logistics Management,(14:1), pp. 1-17.

McLaren, T. S., Head, M., Yuan, Y., and Chan, Y. 2011. “A Multilevel Model for Measuring Fit between a Firm's Competitive Strategies and Information Systems Capabilities,” MIS Quarterly (35:4), pp. 909-929.

Mobile Insider. 2012. “Beyond 'Showrooming': In-Store Mobile Users Want Information, Experiences, a Buddy,” (available online at http://www.mediapost.com/publications/article/ 187153/\#axzz2 DI4Gru21).

Moon, K. L. and Ngai, E. W. T. 2010. "R\&D Framework for an Intelligent Fabric Sample Management System: A Design Science Approach,” International Journal of Operations \& Production Management (30:7), pp. 721-743.

Morschett, D., Swoboda, B., and Foscht, T. 2005. "Perception of Store Attributes and Overall Attitude Towards Grocery Retailers: The Role of Shopping Motives," The International Review of Retail, Distribution and Consumer Research (1:4), pp. 423-447.
Mudambi, S. M., and Schuff, D. 2010. "What Makes a Helpful Online Review? A Study of Customer Reviews on Amazon. com,” MIS Quarterly (34:1), pp. 185-200.

NFC World. 2012. “Casino to Open World's First NFC-enabled Supermarket," (available online at http://www.nfcworld.com/ 2012/09/12/317798/casino-to-open-worlds-first-nfc-enabledsupermarket/).

Ngai, E. W. T., and Gunasekaran, A. 2007. “A Review for Mobile Commerce Research and Applications," Decision Support Systems (43:1), pp. 3-15.

Ngai, E. W. T., Moon, K. K., Riggins, F. J., and Yi, C. Y. 2008. "RFID Research: An Academic Literature Review (1995-2005) and Future Research Directions," International Journal of Production Economics (112:2), pp. 510-520.

Ngai, E. W. T., Poon, J. K. L., Suk, F. F. C. and Ng, C. C. 2009. "Design of an RFID-Based Healthcare Management System Using an Information System Design Theory," Information Systems Frontiers (11:4), pp. 405-417.

Ngai, E. W. T., To, C. K. M., Moon, K. K. L., Chan, T. L. K., Yeung, P. K. W, and Lee, M. C. M. 2009. "RFID Systems Implementation: A Comprehensive Framework and a Case Study,” International Journal of Production Research (48:9), pp. 2583-2612.

Ngai, E. W. T., and Wat, F. K. T. 2002. “A Literature Review and Classification of Electronic Commerce Research,” Information \& Management (39:5), pp. 415-429.

Olivero, N., and Lunt, P. 2004. "Privacy Versus Willingness to Disclose in e-Commerce Exchanges: The Effect of Risk Awareness on the Relative Role of Trust and Control," Journal of Economic Psychology (25:2), pp. 243-262.

Parasuraman, A., Zeithaml, V. A. and Berry, L. L. 1985. “A Conceptual Model of Service Quality and Its Implications for Future Research,” Journal of Marketing (49:4), pp. 41-50.

Parasuraman, A., Zeithaml, V. A., and Berry, L. L. 1988. "SERVQUAL: A Multi-Item Scale for Measuring Customer Perceptions of the Service Quality,” Journal of Retailing (64:1), pp. 12-40.

Pavlou, P. A. and Fygenson, M. 2006. "Understanding and Predicting Electronic Commerce Adoption: An Extension of the Theory of Planned Behavior," MIS Quarterly (30:1), pp. 115-143.

Perdue, B., and Summers, J. 1986. "Checking the Success of Manipulations in Marketing Experiments,” Journal of Marketing Research (23:4), pp. 317-326.

Petty, R., Cacioppo, J., and Schumann, D. 1983. "Central and Peripheral Routes to Advertising Effectiveness: The Moderating Role of Involvement,” Journal of Consumer Research (10:2), pp. 135-146.

Pramatari, K., and Theotokis, A. 2009. "Customer Acceptance of RFID-Enabled Services: A Model of Multiple Attitudes, Perceived System Characteristics and Individual Traits," European Journal of Information Systems (18:6), pp. 541-552.

Ramos, A., Scott, W., and Lloyd, D. 2009. "A Threat Analysis of RFID Passports,” Communications of the ACM (52:12), pp. 38-42.

Razzouk, N. Y., Seitz, V., and Nicolaou, M. 2008. "Consumer Concerns Regarding RFID Privacy: An Empirical Study,” Journal of Global Business and Technology (4:1), pp. 69-78. 
Redden, J. P. and Hoch, S. J. 2009. "The Presence of Variety Reduces Perceived Quantity,” Journal of Consumer Research (36:3), pp. 406-417.

Reuters. 2012. "Walmart Tests iPhone App Checkout Feature” (available online at http://www.reuters.com/article/2012/08/31/ walmart-iphones-checkout-idUSL2E8JVH5B20120831).

RFID Journal. 2012. "JC Penney CEO Predicts RFID Will Help Create a Transformational Shopping Experience” (available online at http://www.rfidjournal.com/article/view/9717).

RFID Journal. n.d. "What Is RFID?” (available online at http://www.rfidjournal.com/article/print/1339).

RIS Research. 2012a. “2012 RIS/IHL Store Systems Study: Expanding Boundaries” (available online at http://risnews.edgl. com/retail-research/2012-RIS/IHL-Store-Systems-Study-Expanding-Boundaries77740).

RIS Research. 2012b. “Mobility in Retail 2012” (available online at http://risnews.edgl.com/retail-research/Mobility-in-Retail201281953).

Rosemann, M., and Vessey, I. 2008. "Towards Improving the Relevance of Information Systems Research to Practitioners: The Role of Applicability Checks,” MIS Quarterly (32:1), pp. $1-22$.

Rust, R. T., Kannan, P. K., and Peng, N. 2002. "The Customer Economics of Internet Privacy," Journal of the Academy of Marketing Science (30:4), pp. 455-464.

Seiders, K., Berry, L L., and Gresham, L. G. 2000. "Attention Retailers: How Convenient is Your Convenience Strategy?," Sloan Management Review (49:3), pp. 79-90.

Seiders, K., Voss, G. B., Grewal, D., and Godfrey, A. L. 2005. "Do Satisfied Customers Buy More? Examining Moderating Influences in a Retailing Context,” Journal of Marketing (69:4), pp. 26-43.

Senecal, S., and Nantel, J. 2004. "The Influence of Online Product Recommendations on Consumers' Online Choices,” Journal of Retailing (80:2), pp. 159-169.

Shaft, T. M., and Vessey, I. 2006. "The Role of Cognitive Fit in the Relationship between Software Comprehension and Modification,” MIS Quarterly (30:1), pp. 29-55.

Sherr, I., and Wingfield, N. 2011. "Play by Play: Sony’s Struggles on Breach," Wall Street Journal (available online at http://online.wsj.com/article/SB1000142405274870481050457 6307322 759299038.html).

Shocker, A. D., Ben-Akiva, M., Boccara, B., and Nedungadi, P. 1991. "Consideration Set Influences on Consumer DecisionMaking and Choice: Issues, Models, and Suggestions,” Marketing Letters (2:3), pp. 181-197.

Smith, H. J., Dinev, T., and Xu, H. 2011. "Information Privacy Research: An Interdisciplinary Review,” MIS Quarterly (35:4), pp. 989-1015.

Srinivasan, S. S., Anderson, R., and Ponnavolu, K. 2002. "Customer Loyalty in e-Commerce: An Exploration of Its Antecedents and Consequences,” Journal of Retailing (78:1), pp. 41-50.

Supply Chain Digest. 2011. "RFID and AIDC News: Do JC Penney, Macy's Announcements Mean RFID to Finally Really Takeoff in Retail?” (available online at http://www.scdigest. com/ontarget/11-11-02-3_RFID_Comeback.php?cid=5140).

Susarla, A., Oh, J. H., and Tan, Y. 2012. "Social Networks and the Diffusion of User-generated Content: Evidence from YouTube,” Information Systems Research (23:1), pp. 23-41.
Thiesse, F. 2007. "RFID, Privacy and the Perception of Risk: A Strategic Framework,” Journal of Strategic Information Systems (16:2), pp. 214-232.

Thong, J. Y. L, Hong, S.-J., and Tam, K. Y. 2006. “The Effects of Post-adoption Beliefs on the Expectation-confirmation Model for Information Technology Continuance,” International Journal of Human-Computer Studies (64:9), pp. 799-810.

Thong, J. Y. L., Venkatesh, V., Xu, X., Hong, S. J., and Tam, K. Y. 2011. "Consumer Acceptance of Personal Information and Communication Technology Services,” IEEE Transactions on Engineering Management (58:4), pp. 613-625.

van der Heijden, H. 2004. "User Acceptance of Hedonic Information Systems,” MIS Quarterly (28:4), pp. 695-704.

van Hoye, G., and Lievens, F. 2009. "Tapping the Grapevine: A Closer Look at Word-of-Mouth as a Recruitment Source," Journal of Applied Psychology (94:2), pp. 341-352.

van Osselaer, S. M., and Janiszewski, C. 2012. "A Goal-Based Model of Product Evaluation and Choice," The Journal of Consumer Research (39:2), pp. 260-292.

Venkatesh, V. 2000. "Determinants of Perceived Ease of Use: Integrating Control, Intrinsic Motivation, and Emotion into the Technology Acceptance Model,” Information Systems Research (11:4), pp. 342-365.

Venkatesh, V. 2006. "Where to Go from Here? Thoughts on Future Directions for Research on Individual-Level Technology Adoption with a Focus on Decision Making,” Decision Sciences (37:4), pp. 497-518.

Venkatesh, V., and Agarwal, R. 2006. “Turning Visitors into Customers: A Usability-Centric Perspective on Purchase Behavior in Electronic Channels,” Management Science (52:3), pp. 367-382.

Venkatesh, V., and Bala, H. 2008. "Technology Acceptance Model 3 and a Research Agenda on Interventions,” Decision Sciences (39:2), 273-315.

Venkatesh, V., Brown, S. A., Maruping, L. M., and Bala, H. 2008. "Predicting Different Conceptualizations of System Use: The Competing Roles of Behavioral Intention, Facilitating Conditions, and Behavioral Expectation,” MIS Quarterly (32:3), pp. 483-502.

Venkatesh, V., and Davis, F. D. 2000. “A Theoretical Extension of the Technology Acceptance Model: Four Longitudinal Field Studies,” Management Science (46:2), pp. 186-204.

Venkatesh, V., Davis, F. D., and Morris, M. G. 2007. "Dead or Alive? The Development, Trajectory, and Future of Technology Adoption Research," Journal of the Association of Information Systems (8:4), pp. 267-286.

Venkatesh, V., Maruping L. M., and Brown, S. A. 2006. "Role of Time in Self-Prediction of Behavior,” Organizational Behavior and Human Decision Processes (100:2), pp. 160-176.

Venkatesh, V., Morris, M. G., Davis, G. B., and Davis, F. D. 2003. "User Acceptance of Information Technology: Toward a Unified View,” MIS Quarterly, pp. 425-478.

Venkatesh, V., and Ramesh, V. 2006. "Web and Wireless Site Usability: Understanding Differences and Modeling Use," MIS Quarterly (30:1), pp. 181-206.

Venkatesh, V., Thong, J. Y. L., Chan, F. K., Hu, P. J. H., and Brown, S. A. 2011. "Extending the Two-Stage Information 
Systems Continuance Model: Incorporating UTAUT Predictors and the Role of Context," Information Systems Journal (21:6), pp. 527-555.

Venkatesh, V., Thong, J. Y. L., and Xu, X. 2012. “Consumer Acceptance and Use of Information Technology: Extending the Unified Theory of Acceptance and Use of Technology,” MIS Quarterly (36:1), pp. 157-178.

Wall Street Journal. 2012. "Wal-Mart is Testing Mobile Checkout" (available online at http://online.wsj.com/article/ SB10000872396390444772804577623721217119252.html).

Warkentin, M., and Willison, R. 2009. "Behavioral and Policy Issues in Information Systems Security: The Insider Threat," European Journal of Information Systems (18:2), pp. 101-105.

Wells, J. D., Valacich, J. S., and Hess, T. J. 2011. "What Signal Are You Sending? How Website Quality Influences Perceptions of Product Quality and Purchase Intentions,” MIS Quarterly (35:2), pp. 373-396.

White, T. B. 2004. "Consumer Disclosure and Disclosure Avoidance: A Motivational Framework,” Journal of Consumer Psychology (14:1/2), pp. 41-51.

Wilcox, K., Vallen, B., Block, L., and Fitzsimons, G. J. 2009. "Vicarious Goal Fulfillment: When the Mere Presence of a Healthy Option Leads to an Ironically Indulgent Decision," Journal of Consumer Research (36:3), pp. 380-393.

Wu, Y., Prybutok, V. R., Koh, C. E., and Hanus, B. 2012. “A Nomological Model of RFID Privacy Concern,” Business Process Management Journal (18:3), pp. 420-444.

Xu, X., Venkatesh, V., and Thong, J. Y. L. 2014. "Effects of ICT Service Innovation and Its Complementary Strategies on Brand Equity and Customer Loyalty in a Consumer Technology Market," Information Systems Research, (25:4) 710-729.

Yoo, B., Donthu, N., and Lee, S. 2000. An Examination of Selected Marketing Mix Elements and Brand Equity,” Journal of the Academy of Marketing Science (28:2), 195-211.

Zeithaml, V. A., Berry, L. L., and Parasuraman, A. 1988. "Communication and Control Processes in the Delivery of Service Quality,” The Journal of Marketing (52:2), pp. 35-48.

Zeithaml, V. A., Parasuraman, A., and Berry, L. L. 1985. "Problems and Strategies in Services Marketing," The Journal of Marketing (49:2), pp. 33-46.

Zhou, T., Lu, Y., and Wang, B. 2010. "Integrating TTF and UTAUT to Explain Mobile Banking User Adoption,” Computers in Human Behavior (26:4), pp. 760-767.

\section{About the Authors}

Viswanath Venkatesh is a Distinguished Professor and Billingsley Chair in Information Systems at the University of Arkansas, where he has been since June 2004. Prior to joining Arkansas, he was on the faculty at the University of Maryland and received his Ph.D. at the University of Minnesota. His research focuses on understanding the diffusion of technologies in organizations and society. His work has appeared or is forthcoming in leading journals in information systems, organizational behavior, psychology, marketing, and operations management. He is widely cited as one of the most influential scholars in business and economics (e.g., highlycited.com), with about 60,000 cites and about 14,000 cites per Google Scholar and Web of Science, respectively. Some of his papers are among the most cited papers published in the various journals, including Information Systems Research, MIS Quarterly, and Management Science. He developed and maintains a web site that tracks researcher and university research productivity (https:// myvisionresearch.com/researchrankings/). He has served on or is currently serving on several editorial boards, including MIS Quarterly. He is a fellow of the AIS and ISS (INFORMS).

John Aloysius is an associate professor of Supply Chain Management in the Sam M. Walton College of Business at the University of Arkansas. His Ph.D. is from Temple University and his research on retail and emerging technologies both at the individual and organizational levels has been funded by Walmart Stores Inc., and the Retail Industry Leaders Association (RILA). His publications have appeared in Information Systems Research, Production and Operations Management, Journal of Operations Management, Organizational Behavior and Human Decision Processes, and other journals.

Hartmut Hoehle is an assistant professor of Information Systems in the Sam M. Walton School of Business at the University of Arkansas. He received a Ph.D. in Information Systems from Victoria University of Wellington, New Zealand. He was a lecturer at the School of Accounting and Business Information Systems, Australian National University. Stemming from his professional experiences gained while working at Deutsche Bank, he is particularly interested in how services and products can be distributed through electronically mediated channels in a retail context. His work has appeared or is forthcoming in MIS Quarterly, European Journal of Information Systems, Journal of the Association for Information Science and Technology, Decision Support Systems, and Journal of Computer Information Systems. He has presented at the International Conference on Information Systems and the European Conference on Information Systems. He has also served as a reviewer for leading journals including MIS Quarterly.

Scot Burton is Distinguished Professor and Tyson Chair in Food and Consumer Products Retailing, Department of Marketing, Sam M. Walton College of Business, University of Arkansas. His research interests include effects of information provision to consumers, pricing and promotion issues, and consumer welfare and public policy. He has a number of publications in various journals in marketing, psychology and consumer health, including Journal of Marketing, Journal of Marketing Research, Journal of Consumer Research, Journal of Applied Psychology, American Journal of Public Health, American Journal of Health Promotion, Journal of Retailing, Journal of the Academy of Marketing Science, Journal of Management, Journal of Business Logistics, Public Opinion Quarterly, Organizational Behavior and Human Decision Processes, Journal of Public Policy \& Marketing, and others. Findings from his research have received substantial interest from the media and been discussed in diverse business outlets including the Wall Street Journal, (Bloomberg) Business Week, US News \& World Report, $N P R, M S N, Y a h o o$, and scores of other health and business journals around the world. He has received several national awards for his research, teaching, and reviewing. He currently serves as a Special External Consultant to the FDA Risk Communication Advisory Committee. 


\section{Appendix A}

\section{Respondent Demographics}

\begin{tabular}{|c|c|c|c|c|c|}
\hline \multirow[b]{2}{*}{ Demographic } & \multirow[b]{2}{*}{ Category } & \multicolumn{2}{|c|}{ Experiment 1} & \multicolumn{2}{|c|}{ Experiment 2} \\
\hline & & $n=227$ & $\%$ & $n=221$ & $\%$ \\
\hline \multirow{2}{*}{ Gender } & Men & 145 & 64 & 139 & 63 \\
\hline & Women & 82 & 36 & 82 & 37 \\
\hline \multirow{6}{*}{ Age groups } & Under 20 & 12 & 5 & 5 & 2 \\
\hline & $20-29$ & 76 & 33 & 80 & 36 \\
\hline & $30-39$ & 77 & 34 & 84 & 38 \\
\hline & $40-49$ & 24 & 11 & 20 & 9 \\
\hline & $50-59$ & 24 & 11 & 17 & 8 \\
\hline & 60 or older & 14 & 6 & 15 & 7 \\
\hline \multirow{9}{*}{ Income (Annual, in USD) } & $0-10,000$ & 10 & 4 & 8 & 4 \\
\hline & $10,000-19,000$ & 21 & 9 & 17 & 8 \\
\hline & $20,000-29,000$ & 30 & 13 & 21 & 10 \\
\hline & $30,000-39,000$ & 40 & 18 & 38 & 17 \\
\hline & $40,000-49,000$ & 32 & 14 & 35 & 16 \\
\hline & $50,000-74,000$ & 32 & 14 & 31 & 14 \\
\hline & $75,000-99,000$ & 35 & 15 & 44 & 20 \\
\hline & $100,000-150,000$ & 20 & 9 & 17 & 8 \\
\hline & Over 150,000 & 7 & 3 & 10 & 5 \\
\hline
\end{tabular}




\section{Appendix B}

\section{Scales Used}

\begin{tabular}{|c|c|}
\hline \multirow{2}{*}{$\begin{array}{l}\text { Constructs } \\
\text { (measurement source) }\end{array}$} & Items \\
\hline & Technology adoption outcomes \\
\hline \multirow{3}{*}{$\begin{array}{l}\text { Intention to use } \\
\text { (Venkatesh et al. 2003) }\end{array}$} & I would use mobile shopping to shop in the store. \\
\hline & I intend to use mobile shopping the next time I see it in the store. \\
\hline & I will not use mobile shopping the next time I see the system in the store. ${ }^{*}$ \\
\hline \multirow{4}{*}{$\begin{array}{l}\text { Perceived usefulness } \\
\text { (Venkatesh et al. 2003) }\end{array}$} & I found using mobile shopping in the store to be useful. \\
\hline & Using mobile shopping in the store added value to my shopping experience. \\
\hline & The experience of using mobile shopping in the store was useful to me. \\
\hline & $\begin{array}{l}\text { I believe that the experience of using mobile shopping in the store added value to the overall } \\
\text { service. }\end{array}$ \\
\hline \multirow{4}{*}{$\begin{array}{l}\text { Perceived ease of use } \\
\text { (Venkatesh et al. 2003) }\end{array}$} & My interaction with mobile shopping in the store was clear and understandable. \\
\hline & It was easy for me to become skillful at using mobile shopping in the store. \\
\hline & I found mobile shopping easy to use in the store. \\
\hline & Learning to operate mobile shopping in the store was easy for me. \\
\hline & Security beliefs towards shopping \\
\hline \multirow{4}{*}{$\begin{array}{l}\text { Privacy concerns } \\
\text { (Bart et al. 2005) }\end{array}$} & I feel comfortable giving personal information on this retailer.* \\
\hline & I feel comfortable shopping at this retailer.* \\
\hline & The retailer clearly explained how user information will be used.* \\
\hline & Information regarding security of payments is clearly presented.* \\
\hline \multirow{5}{*}{$\begin{array}{l}\text { Trust } \\
\text { (Gefen et al. 2003; Van } \\
\text { der Heijden 2004) }\end{array}$} & This store is trustworthy. \\
\hline & I trust this store keeps my best interests in mind. \\
\hline & I think it makes sense to be cautious with this store. \\
\hline & This retailer has more to lose than to gain by not delivering on their promises. \\
\hline & This store's behavior meets my expectations. \\
\hline \multirow{4}{*}{$\begin{array}{l}\text { Risk } \\
\text { (Kim et al. 2009) }\end{array}$} & $\begin{array}{l}\text { Purchasing from this retailer (using mobile shopping) would involve product risk (i.e., not } \\
\text { working, defective product). }\end{array}$ \\
\hline & $\begin{array}{l}\text { Purchasing from this retailer (using mobile shopping) would involve financial risk (i.e., fraud, hard } \\
\text { to return). }\end{array}$ \\
\hline & My overall perception of risk related to buying from the retailer (using mobile shopping) is high. \\
\hline & Shopping outcomes \\
\hline \multirow{3}{*}{$\begin{array}{l}\text { Convenience } \\
\text { (Donthu and Gilliland } \\
\text { 1996) }\end{array}$} & It was convenient to find information on products. \\
\hline & I found it complicated to find products at this store. ${ }^{*}$ \\
\hline & It is convenient to shop from this retailer. \\
\hline \multirow{3}{*}{$\begin{array}{l}\text { Word-of-mouth } \\
\text { (Brady et al. 2012) }\end{array}$} & I would recommend visiting this retailer to friends. \\
\hline & I would say good things about this retailer to others. \\
\hline & I would encourage friends and relatives to visit this retailer. \\
\hline \multirow{3}{*}{$\begin{array}{l}\text { Customer service- } \\
\text { quality } \\
\text { (Yoo et al. 2000) }\end{array}$} & The retailer's customer service was of high quality. \\
\hline & The retailer's customer service was always functional. \\
\hline & The retailer's customer service was very reliable. \\
\hline \multirow{4}{*}{$\begin{array}{l}\text { Attitude toward a } \\
\text { retailer } \\
\text { (Bruner 2009) }\end{array}$} & My overall attitude toward the retailer is: \\
\hline & Unfavorable/favorable \\
\hline & Bad/good \\
\hline & Negative/positive \\
\hline
\end{tabular}

*These items were reverse coded. 
Copyright of MIS Quarterly is the property of MIS Quarterly and its content may not be copied or emailed to multiple sites or posted to a listserv without the copyright holder's express written permission. However, users may print, download, or email articles for individual use. 